CDD: 185

\title{
OS SEIS REQUISITOS DAS PREMISSAS DA DEMONSTRAÇÃO CIENTÍFICA EM ARISTÓTELES (SEGUNDOS ANALÍTICOS I 2)
}

\section{LUCAS ANGIONI}

Departamento de Filosofia

Instituto de Filosofia e Ciências Humanas - IFCH

Universidade Estadual de Campinas

Cidade Universitária Zeferino $V$ az.

13083-970 CAMPINAS - SP

BRASIL

angioni@unicamp.br

Received: 17.10.20II; Accepted: 16.04.2012

Resumo: Discuto neste artigo os seis requisitos que Aristóteles propõe para as premissas das demonstrações científicas em Segundos Analíticos I 2, 71b20-33. Pretendo mostrar que os seis requisitos não respaldam a interpretação "axiomatizante". Ao contrário, os seis requisitos podem ser entendidos consistentemente de acordo com uma interpretação segundo a qual o traço mais fundamental da demonstração científica consiste na explicação pela causa apropriada.

Palavras-chave: Demonstração. Silogística. Causalidade. Essencialismo. Explicação. Predicação.

\section{THE SIX REQUIREMENTS OF PREMISES OF SCIENTIFIC PROOF IN ARISTOTLE (POSTERIOR ANALYTICS A 2)}

\begin{abstract}
I discuss in this paper the six requirements Aristotle advances at Posterior Analytics A-2, 71b20-33, for the premisses of a scientific demonstration. I argue that the six requirements give no support for an intepretation in terms of "axiomatization". Quite on the contrary, the six requirements can be consistently understood in a very different picture, according to which the most basic feature of a scientific demonstration is to explain a given proposition by its appropriate cause.
\end{abstract}

Keywords: Demonstration. Syllogistic. Causality. Essencialism. Explanation. Predication. 
Em 71b20-33, Aristóteles introduz seis características que devem ser satisfeitas pelas premissas de uma demonstração científica. Nada indica que tal caracterização das premissas é a mais importante que encontramos no conjunto dos Segundos Analíticos. Aristóteles volta a falar de requisitos que as proposições de uma demonstração devem satisfazer em diversos outros contextos ${ }^{1}$, e acrescenta muitos pontos que não estavam contidos em 71b20-33. No entanto, a caracterização das premissas em $71 \mathrm{~b} 20-33$ tem dois aspectos proeminentes que quero discutir neste artigo. Em primeiro lugar, ela se refere a uma definição prévia de conhecimento científico, da qual parece depender. Aristóteles, de fato, introduz seu ponto do seguinte modo:

"se o conhecer cientificamente é como propusemos, é necessário que o conhecimento demonstrativo provenha de itens verdadeiros etc." (71b19-21).

Não é fácil, no entanto, compreender a relação que as seis características das premissas guardam com o que foi dito antes. Não é de imediato claro se Aristóteles se refere à definição de conhecimento científico oferecida em 71b9-12, ou se refere à caracterização da demonstração como um silogismo, em 71b17-19, ou a ambas as coisas.

$\mathrm{O}$ segundo ponto que quero discutir diz respeito ao fato de que, em comparação com outras caracterizações das premissas da demonstração, a que encontramos em 71b20-33 parece favorecer a interpretação segundo a qual Aristóteles teria concebido a noção de demonstração independentemente de sua formulação silogística ${ }^{2}$. De

1 Em 73b16-18, Aristóteles introduz o requisito de que as premissas (ou mesmo as três proposições) da demonstração científica devem ser predicações per se; em 74b11-8, Aristóteles afirma que as premissas devem introduzir princípios necessários; em 75b10-11 e 76a8-9, introduz o requisito de que os três termos do silogismo devem ser "congêneres".

${ }^{2}$ Cf. Barnes (1981, p. 33-4): "Although the Analytics presents Syllogistic and Apodeictic as a single system, the former a necessary propaedeuctic to the latter, the Syllogism is in fact an incidental adjunct to the theory of

Manuscrito - Rev. Int. Fil., Campinas, v. 35, n. 1, p. 7-60, jan.-jun. 2012. 
acordo com essa interpretação, ao menos três requisitos das premissas poderiam ser entendidos sem nenhuma referência à silogística: as premissas têm de ser primeiras, imediatas e mais cognoscíveis que a conclusão.

Pretendo mostrar que os seis requisitos das premissas de uma demonstração propostos em 71b20-33 estão diretamente conectados com a definição de conhecimento científico dada em 71b9-12 e, além do mais, pressupõem a estrutura silogística da demonstração. Para tanto, discutirei cada um dos seis requisitos, em separado, e depois farei uma avaliação de seu conjunto. Não poderei discutir, nos limites deste artigo, a definição de conhecimento científico introduzida em 71b9-12. Pressuporei alguns pontos em favor dos quais argumentei em Angioni (2007). No entanto, procurarei mostrar que o bom entendimento das seis exigências das premissas nos levam a descartar duas leituras que, no mais das vezes, aparecem conectadas na literatura: a interpretação da demonstração como uma axiomatização do conhecimento, ${ }^{3}$ e o modelo de apodítica pré-silogística, ficção proposta por Barnes ${ }^{4}$ e que gozou de algum sucesso. Essas interpretações dependem de um pressuposto exegético básico: elas assumem que a tarefa essencial que compete à demonstração científica, segundo Aristóteles, seria estabelecer e certificar que são verdadeiras certas proposições que se afiguravam como problemáticas. ${ }^{5}$ A demonstração seria um procedimento de

demonstration: the theory can be formulated without reference, explicite or implicit, to Syllogistic, and it could have been discovered by someone who knew nothing whatever about the Syllogism".

${ }^{3}$ Cf. Scholz (1975, p. 50): "Aristotle presented his axiomatic theory in the two books of the second part of his 'analytical' investigation, the so-called Posterior Analytics"; Barnes (1975, p. 65): "a demonstrative science is an axiomatised deductive system comprising a finite set of connected apodeixeis or demonstrations".

${ }^{4}$ Ver nota 2.

5 Ver Corcoran (2009, p. 1): "a demonstration, which normally proves a conclusion not previously known to be true, is an extended argumentation

Manuscrito - Rev. Int. Fil., Campinas, v. 35, n. 1, p. 7-60, jan.-jun. 2012. 
prova mediante o qual premissas verdadeiras (e, em última instância, necessariamente verdadeiras) permitiriam decidir que certas proposições, cujo valor de verdade antes se ignorava, são também verdadeiras. Em contraste com esse pressuposto, a interpretação alternativa que proponho afirma que a demonstração científíca se define pela tarefa essencial de explicar adequamente, pelas causas primeiras, por que são verdadeiras certas proposições que já sabemos que são verdadeiras. ${ }^{6}$

\section{Premissas Verdadeiras}

O primeiro requisito para as premissas da demonstração científica consiste em serem verdadeiras. A justificação desse requisito é simples. Não se pode conhecer - muito menos se pode conhecer cientificamente - aquilo que não é o caso (71b25-26). Essa tese pressupõe a noção de verdade como correspondência entre enunciados declarativos e fatos a que tais enunciados se pretendem reportar. ${ }^{7}$ Poderia haver alguma dificuldade do seguinte modo. Considere-se que cisnes não são listrados. É verdadeira a proposição que descreve essa situação, "cisnes não são listrados" ou "nenhum cisne é listrado".

beginning with premises known to be truths and containing a chain of reasoning showing by deductively evident steps that its conclusion is a consequence of its premises" (grifos meus). Mignucci (2007, p. 152), compreende "indemonstrabilidade" em termos de "indecidibilidade": como se demonstrar fosse decidir que é verdadeira (com base nas premissas) uma proposição problemática.

${ }^{6}$ Essa linha de interpretação se encontra em Kosman (1973), Burnyeat (1981), McKirahan (1992) e, de certo modo, Taylor (1990, p. 116-7). Há várias diferenças entre esses autores, mas todos eles enfatizam que a preocupação central da teoria de Aristóteles não é a noção de prova como meio de decidir (ou certificar) o valor de verdade de uma proposição. Por outro lado, as críticas de Tierney (2001, p. 150-152), às interpretações explanatórias fundamse em confusão geral a respeito das noções de explicação, causa e essência.

${ }^{7}$ Cf. Porchat (2000, p. 83-4).

Manuscrito - Rev. Int. Fil., Campinas, v. 35, n. 1, p. 7-60, jan.-jun. 2012. 
Alguém, então, poderia objetar: não poderíamos ter conhecimento desse fato negativo? Sabemos que cisnes não são listrados, portanto (se poderia argumentar), temos conhecimento de algo que não é o caso.

Esse problema, no entanto, é artificioso e se funda em compreensão incorreta do objeto que, precisamente, se conhece. Aristóteles diz que não se pode conhecer cientificamente aquilo que não é o caso. Mas cisnes serem listrados é precisamente algo que não é o caso, e é desse tipo de "não-ser" que Aristóteles fala neste contexto. Sabemos que cisnes não são listrados, mas isso significa que cisnes serem não-listrados é algo que é o caso.

Alguém poderia objetar que essa defesa do argumento de Aristóteles é ainda insuficiente porque apenas explicou porque deve ser verdadeira a proposição que se conhece por demonstração, isto é, a conclusão, mas não explicou porque se poderia inferir que os princípios devem ser verdadeiros. ${ }^{8}$ Aristóteles fia-se em algo que ele declara explicitamente em Primeiros Analíticos 53b7-10: ainda que se possa ter um argumento válido no qual uma conclusão verdadeira é deduzida de uma ou duas premissas falsas, não se pode jamais explicar o porquê da conclusão ser verdadeira por premissas falsas. Conhecer por que a conclusão é verdadeira exige conhecimento de premissas que sejam também verdadeiras. Portanto, como não se pode ter conhecimento (no sentido de saber que é o caso) de uma conclusão falsa, é claro que os princípios pelos quais se tem conhecimento (no sentido de saber por que é o caso a conclusão) não podem ser falsos.

Resolvido o aparente impasse, nada mais resta a dizer sobre esse requisito das premissas, ao menos quando ele é considerado em si mesmo. Voltaremos a falar algo sobre ele quando considerarmos as demais características das premissas.

8 Barnes (1993, p. 94). Mignucci (2007, p. 153), sugere que Aristóteles pressupõe algo como "há conhecimento científico das premissas da demonstração".

Manuscrito - Rev. Int. Fil., Campinas, v. 35, n. 1, p. 7-60, jan.-jun. 2012. 


\section{Premissas primeiras, imediatas (e indemonstráveis).}

O segundo requisito reza que as premissas da demonstração científica devem ser primeiras. Há vários indícios de que esse segundo requisito deve ser considerado em conjunto com o terceiro, como se ambos formassem um par (ou fossem designações alternativas para uma mesma característica básica) ${ }^{9}$. De fato, Aristóteles de início anuncia que as premissas devem ser "primeiras, imediatas etc." (71b21), e, ao retomar esses requisitos no intuito de lhes justificar a pertinência, parece não apenas trocar "imediatas" por "indemonstráveis", mas também combinar esta última expressão com o adjetivo "primeiras" (71b26-27): a justificação de ambas parece ser a mesma.

Deve-se observar, porém, que a noção de "primeiro" reaparece em 72a5-7: nesse contexto, "primeiros" são os princípios apropriados. A noção de "princípio apropriado" já havia aparecido em 71b23, mas sem estar associada estritamente à indemonstrabilidade ou primariedade dos princípios: "apropriados" são os princípios que satisfazem conjuntamente os seis requisitos.

Alguns associam a noção de "primeiro" com a noção de axiomatização ${ }^{10}$. As "evidências" para tal leitura, no entanto, são escassas ou nulas. Em 71b27-29, Aristóteles justifica a primariedade e a indemonstrabilidade dos princípios pelo argumento de que, se os princípios fossem demonstráveis, não se teria conhecimento deles sem demonstração. A conseqüência indesejada que daí se segue, no entanto, é apenas sugerida: para ter conhecimento dos princípios, deveríamos obter demonstrações dos mesmos, mas, desse modo, se prosseguiria ao infinito, de modo que não poderia haver demonstração de nada (cf.

\footnotetext{
${ }^{9}$ Cf. Mignucci (2007, p. 152); Barnes (1993, p. 94); McKirahan (1992, p. 26).

${ }^{10}$ Cf. Mignucci (2007, p. 152): "una proposizione primitiva di una teoria non solo è indimostrabile in essa, ma ha anche uno statuto epistemico speciale, per il quale possiamo qualificarla come un principio o assioma della teoria" (grifos meus); Scholz (1975, p. 52, 55-56).
}

Manuscrito - Rev. Int. Fil., Campinas, v. 35, n. 1, p. 7-60, jan.-jun. 2012. 
72b8-11). ${ }^{11}$ No entanto, evitar o regresso ao infinito é um argumento que se ajusta igualmente bem à exigência de encontrar a causa última, que completa uma série explanatória e não requer nenhuma explicação ulterior (cf. 85b27-30). Pode-se talvez dizer que "primeira" é a proposição cuja verdade não precisa ser estabelecida por nenhum argumento anterior. Alguns intérpretes, no entanto, acrescentam que "primeira" é a proposição cuja verdade já está garantida por si mesma, pois a mera compreensão de seu sentido impõe a convicção de que ela é o caso. ${ }^{12}$ Por isso, acrescentam que qualquer tentativa de provar que uma proposição primeira é verdadeira seria fadada ao fracasso. Entende-se, assim, que uma proposição primeira é também imediata no sentido de que (i) sua verdade se impõe por si mesma e (ii) é impossível prová-la (ou demonstrá-la) por qualquer procedimento formalmente válido (ou correto). E o fato de Aristóteles arrolar os requisitos do modo como arrolou - "verdadeiras, primeiras e imediatas" - tenderia a respaldar a idéia de que, quando Aristóteles fala em premissas primeiras e imediatas, o que está em questão é o modo pelo qual a verdade dessas premissas se dá a conhecer e se impõe à nossa convicção: ${ }^{13}$ a verdade das mesmas se impõe por si mesma e não precisa (nem poderia) ser estabelecida por um procedimento de prova formal, ou, se pudesse ser deduzida por um argumento válido, ao menos não poderia ser deduzida de premissas verdadeiras ${ }^{14}$. As premissas verdadeiras, primeiras e

${ }^{11}$ Cf. Filopono 27.18-21; McKirahan (1992, p. 25).

${ }^{12}$ Cf. Scholz (1975, p. 56): "these undemonstrable sentences are distinguished by the fact that one need only understand the meaning of the terms they contain in order to know that the assertions they make are true. In short, they are distinguished by the fact that they are evident ex terminis".

${ }^{13}$ Cf. Scholz (1975, p. 56-7).

${ }^{14}$ Esta última observação marca a posição de Mignucci (2007, p. 152): se AaB é indemonstrável, então, ainda que seja possível encontrar outras proposições das quais se possa deduzir validamente $\mathrm{AaB}$, não se pode encontrar outras proposições verdadeiras das quais ela pudesse ser deduzida, e apenas nisso parece consistir a indemonstrabilidade: "AaB non è suscetibile di Manuscrito - Rev. Int. Fil., Campinas, v. 35, n. 1, p. 7-60, jan.-jun. 2012. 
imediatas seriam, portanto, os axiomas indemonstráveis do sistema demonstrativo. ${ }^{15}$

No entanto, essa interpretação não se sustenta. Se atentarmos para o uso que Aristóteles faz da expressão "primeiro" nos Segundos Analíticos, veremos que é difícil atribuir-lhe o sentido de algo axiomaticamente verdadeiro, cuja verdade não pudesse ser estabelecida por nenhuma prova formalmente válida. "Primeiras" são as proposições na qual a relação entre sujeito e predicado é autoexplanatória e não pode ser explicada de modo apropriado por nenhum termo mediador. Mas a tese de que (1) é impossível explicar apropriadamente uma proposição por uma causa anterior não se confunde nem com a tese de que (2) é impossível deduzir tal proposição primeira por qualquer procedimento formalmente correto, ${ }^{16}$ nem com a tese de que (3) a convicção da verdade de tal

dimostrazione, nel senso che non ci sono premesse vere da cui dedurla" (grifos do autor). Barnes (1993, p. 95), acertadamente nota que a indemonstrabilidade não acarreta a imediaticidade meramente formal. Filopono, 24.14, interpreta a combinação "primeiras e imediatas" em termos de "indemonstráveis e autoevidentes" (autopiston $=$ que impõem por si mesmas a crença de que são verdadeiras).

${ }^{15}$ Cf. Mignucci (2007, p. 152); Scholz (1975, p. 55-57); Barnes (1993, p. xii): "the essential thesis of Book A is simple and striking: the sciences are properly expounded in formal axiomatized systems". A inspiração clássica para essa interpretação parece provir de Temístio, 6.9-14: "se [as premissas assumidas] não podem ser demonstradas por outras e, em geral, não requerem demonstração, mas são evidentes em si mesmas e confiáveis por si mesmas ("autothen pistoi" = por si mesmas impõem a convicção de que são verdadeiras), são também primeiras, as quais os antigos chamaram de axiomas e proposições imediatas, às quais seria preciso reduzir todas as outras, e pelas quais seria preciso demonstrar as que se propõem no silogismo científico. Por isso, também as chamam de princípios da demonstração" (tradução minha).

${ }^{16}$ Cf. Lear (1980, p. 78): "from there being no Q prior to P it does not follow that there is no Q from which knowledge of $\mathrm{P}$ may be derived. It only follows that there is no $\mathrm{Q}$ of which knowledge is essential if one is to have knowledge of $\mathrm{P}$. [...] To assert that a principle $\mathrm{P}$ is primitive is not, in itself, to assert that

Manuscrito - Rev. Int. Fil., Campinas, v. 35, n. 1, p. 7-60, jan.-jun. 2012. 
proposição se impõe pela própria compreensão de seu sentido intrínseco. Aristóteles defende a primeira tese, mas não defende nem a segunda, nem a terceira, como procuraremos mostrar pelo exame de algumas passagens.

Em Segundos Analíticos I 2, 72a28, 31, o termo "primeiro" é usado em um contexto que parece favorecer a consideração de requisitos epistemológicos para as premissas da demonstração científica. Esse seria o contexto propício para a defesa da tese (3) acima mencionada, pois Aristóteles parece falar de condições para a convicção de que algo é o caso e parece sugerir que os princípios primeiros seriam opostos aos princípios dos quais se poderia derivar o silogismo do "erro contrário". No entanto, Aristóteles está longe de defender a tese (3), pois apenas afirma que conhecemos mais os "itens primeiros" e temos neles mais confiança do que na conclusão. Mas isso não quer dizer que a convicção da verdade dos princípios se impõe pela mera compreensão de seu sentido. Em Segundos Analíticos I 10, 76a32-36, Aristóteles novamente teria oportunidade de dizer que os "itens primeiros", por eles mesmos, impõem a convicção de que são o caso e não poderiam ser provados por nenhuma dedução correta. Ele apenas diz, no entanto, que assumimos o que os "itens primeiros" significam, e acrescenta que é preciso assumir (lambanein) que os princípios são o caso. Ele está longe de ter dito ou sugerido que a convicção de que os princípios são o caso seria uma conseqüência necessária da compreensão de seu sentido.

Por outro lado, em Segundos Analíticos I 13, 78a25-26, Aristóteles usa "primeiro" como adjetivo de "aition" - em português, temos de mudar o gênero e traduzir por "causa primeira". Como fica claro pelo uso de exemplos, a "causa primeira" é um termo mediador que, do ponto de vista extensional, deve ser conversível com o termo

one could not come to have knowledge of $\mathrm{P}$ through any other premisses Q. It only means that one need not know any other premisses $Q$ in order to know P".

Manuscrito - Rev. Int. Fil., Campinas, v. 35, n. 1, p. 7-60, jan.-jun. 2012. 
maior, cuja atribuição ao termo menor (na conclusão) é o que se quer explicar. ${ }^{17}$ Assim, quando a causa primeira é captada como termo mediador, a premissa maior do silogismo de primeira figura se torna conversível e, por isso mesmo, a premissa menor pode ser provada por meio da conclusão original e da conversão da maior. Ora, a premissa menor certamente tem direitos ao título de "item primeiro", pois é ela que liga o sujeito proposto no explanandum à causa que explica por que a esse sujeito se atribui o predicado que se lhe atribui na conclusão. Assim, uma premissa menor nessas condições - que estão longe de ser "periféricas" ou "excepcionais", mas constituem o caso central e paradigmático para Aristóteles -, embora possa ser considerada como "primeira" no sentido de que relaciona o termo menor ao termo mediador primeiro, pode ser provada por um silogismo correto. ${ }^{18}$

Alguém poderia objetar que meu arrazoado é improcedente porque aquilo que Aristóteles fala sobre a "causa primeira", que é um termo, não poderia ser transferido sem mais para as premissas “primeiras". No entanto, a objeção não procede. De fato, a causa primeira introduz um termo, não uma proposição: o termo mediador. No entanto, proposições predicativas só podem ser chamadas de "primeiras" porque contêm um predicado primeiro - qualquer que seja o sentido mais preciso de "primeiro". ${ }^{19}$

Os mesmos resultados podem ser obtidos pelo exame da noção de "imediato". Alguns julgam que a noção de "imediato" sugere a mera

17 Tratarei desse assunto com mais detalhe na seção III. Cf. McKirahan (1992, p. 214-6).

${ }^{18}$ Uso "silogismo correto" para designar o silogismo que, além de válido, é constituído por proposições verdadeiras.

19 Mesmo se alguém considerasse a noção de "primeiro", neste contexto, de modo puramente formal, como aquela proposição que não pudesse ser estabelecida por nenhum procedimento dedutivo, teria de admitir que a proposição é chamada de "primeira" na medida em que apresenta um termo primeiro, cuja relação com o outro não pode ser deduzida por nenhuma proposição que lhe fosse anterior.

Manuscrito - Rev. Int. Fil., Campinas, v. 35, n. 1, p. 7-60, jan.-jun. 2012. 
impossibilidade de se deduzir (por um procedimento qualquer formalmente válido) as premissas da demonstração. Além do mais, a interpretação axiomatizante tende a projetar sobre a expressão "imediato" as conotações epistemológicas que redundam na tese (3) acima mencionada. De "imediato" para "auto-evidente", o passo é tão tentador que parece ter-se sedimentado como algo garantido, sobre o qual não paira nenhuma dúvida razoável. ${ }^{20}$

No entanto, "imediato" pode querer dizer duas coisas bem distintas na teoria da demonstração. A expressão grega para "imediato" é "ameson", a qual, aplicada a uma proposição, remete diretamente à silogística e à forma predicativa das proposições aptas ao cálculo silogístico. ${ }^{21}$ De fato, "ameson" quer dizer "sem meson", e "meson" é a expressão usada por Aristóteles para aquilo que, na tradição, sedimentou-se no jargão "termo médio", mas que pode ser muito mais bem traduzido como "termo mediador". ${ }^{22}$ A expressão "amesos protasis" - "proposição imediata" - introduz uma proposição predicativa na qual a relação entre sujeito e predicado é imediata, seja no sentido de que não foi, em dado contexto argumentativo, obtida por um termo mediador, seja no sentido mais forte de que não poderia de

${ }^{20}$ Cf. Scholz (1975, p. 55-58). Ver o trecho de Temístio citado na nota 15.

${ }^{21}$ Cf. McKirahan (1992, p. 25); Smith (2009, p. 53-4); Barnes (1993, p. 94) e (1981, p. 31). Embora reconheça que "amesos" tem um sentido meramente formal que remete à impossibilidade de se encontrar um mediador apto a gerar uma dedução silogística válida, Barnes não explora as conseqüências apropriadas desse ponto.

22 Para tal tradução, ver Angioni (2002) e (2004). A expressão “meson” designa o termo "comum" (41a10) a ambas as premissas", ou seja, o termo que se relaciona a cada um dos extremos de modo a garantir uma dedução válida sobre a atribuição do extremo maior ao menor (cf. 41a2-4, 11-12). Fica claro, pelos contextos de "proof-search" que predominam em Primeiros Analíticos I 23-28, que "meson" é o termo que opera a mediação entre os extremos e permite deduzir a relação entre eles.

Manuscrito - Rev. Int. Fil., Campinas, v. 35, n. 1, p. 7-60, jan.-jun. 2012. 
modo algum ser obtida por um termo mediador. ${ }^{23}$ Parece certo que, no contexto em que se descrevem os requisitos das premissas da demonstração, "proposição imediata" remete a uma proposição na qual a relação entre os termos não pode ser obtida por nenhum mediador. ${ }^{24}$ No entanto, ainda paira uma ambivalência decisiva sobre a expressão

${ }^{23}$ Cf. Primeiros Analíticos 48a 33, para "amesos" no sentido mais fraco de premissa que foi, em dado contexto, assumida sem um mediador (embora possa ser provada por um mediador): o exemplo que Aristóteles parece ter em mente é "todo triângulo tem 2R". Cf. Lear (1980, p. 78-80), para boa consideração sobre essa opção mais branda. Ver também Hintikka (1972, p. 60). É bom lembrar que há, ainda, outra opção (cf. Filopono, 24.16-21): é imediata a proposição que não requer um mediador para que acreditemos que ela é verdadeira. Seriam imediatas neste sentido proposições singulares, como "este é Sócrates" (cf. 24.22), que se impõem como verdadeiras pela mera percepção (cf. Temístio, 6.29-31). É claro, no entanto, que essas proposições são irrelevantes no contexto da demonstração científica.

${ }^{24}$ Pode-se questionar esse ponto, porém. Porchat (2000, p. 94), tende a dissolver o requisito da imediaticidade na noção de "causalidade próxima da coisa a demonstrar", como se "imediata" fosse a premissa que, em relação à conclusão que se quer provar, lhe fosse, na ordem da causalidade, a mais próxima, de tal modo que não se admitiria, entre tal premissa (ou premissas) e a conclusão, outra causa intermediária (expressa em uma premissa intermediária). A proposta de Porchat é engenhosa e muito melhor que as interpretações que tendem a interpretar a "imediatez" em termos puramente formais, sem nenhuma referência à causalidade. No entanto, falta-lhe ainda uma fundamentação exegética apropriada: é preciso mostrar que "ameson" pode funcionar desse modo. É como se o adjetivo "ameson", aplicado a uma premissa, dissesse que tal premissa, no contexto daquele argumento, é tal que fornece a explicação apropriada (ou a causa primeira) para a conclusão, sendo irrelevante saber se, fora desse contexto, a premissa em si mesma pudesse ser explicada por outra causa anterior. Essa interpretação também se opõe ao clichê, difundido desde os comentadores antigos, de que os três primeiros requisitos cabem às premissas em si mesmas, independentemente da relação das mesmas com a conclusão (cf. Ross (1949, p. 509); Barnes (1993, p. 93); McKirahan (1992, p. 24)). No entanto, o uso de "ameson" em contextos como 75b40 é uma pedra no sapato de uma interpretação como a de Porchat.

Manuscrito - Rev. Int. Fil., Campinas, v. 35, n. 1, p. 7-60, jan.-jun. 2012. 
"poder ser obtida por um termo mediador". Aristóteles reconhece clara distinção entre estabelecer que uma proposição é verdadeira por meio de um silogismo correto e explicar por que uma proposição é verdadeira por meio de um silogismo cujo termo mediador capta a causa (primeira, adequada) do fato representado na conclusão. ${ }^{25} \mathrm{Ou}$ seja, Aristóteles propõe uma distinção entre, de um lado, a mera relação de conseqüência entre premissas e conclusão e, de outro, a relação explanatória entre premissas e conclusão. A segunda relação envolve a primeira, mas não vice-versa. Se há uma relação explanatória entre premissas e conclusão, há entre elas uma relação de conseqüência, mas não inversamente: nem toda relação de conseqüência é uma relação explanatória. Do mesmo modo, todo silogismo cujo mediador capta a causa adequada do fato relatado na conclusão é um silogismo correto que também estabelece que a conclusão é verdadeira, mas não é o caso que todo silogismo correto, que estabelece a verdade da conclusão com base nas verdade das premissas, também explica pela causa primeira por que a conclusão é verdadeira. O problema é que Aristóteles usa o termo "meson" ("mediador") de dois modos, condizentes com essa distinção: ele usa "meson", por um lado, para designar o termo mediador que, quando está corretamente relacionado com os extremos, é apto a estabelecer que a conclusão é verdadeira; ${ }^{26}$ por outro, para designar o termo mediador que é a causa pela qual se explica apropriadamente por que a conclusão é verdadeira. Este segundo uso parece ser proeminente em Segundos Analíticos II, como pode ser bem detectado em passagens como 93b13, 93b26, 95b14, 98b35 e 99a21-22 (cf. 99a25, "primeiro mediador" = "causa primeira") - e esse uso foi bem justificado desde o início do livro II, em passagens decisivas como 89b38-90a1 (“quando investigamos o 'por que’ ou o 'o que é', após ter

${ }^{25}$ Cf. Segundos Analíticos 78a36-38; 78b13-28. Cf. McKirahan (1992, p. 213218).

${ }^{26}$ Cf. 79a35; 80b18ss.; 84b20-21. Já na silogística pura e simples, o "mediador" é o termo que garante a mera validade do argumento (cf. 25b 33ss.; 41a3, 11).

Manuscrito - Rev. Int. Fil., Campinas, v. 35, n. 1, p. 7-60, jan.-jun. 2012. 
conhecido ou que ou se é [...], estamos a buscar o que é o mediador"), 90a6-7 ("o mediador é a causa, e é ela que se investiga em todos esses casos”) e 90a9-11 (“a causa de ser não isto aqui ou aquilo ali, mas ser sem mais a essência, ou a causa de ser não sem mais, mas ser algo que se atribui per se ou por concomitância, eis o que é o mediador"). ${ }^{27}$

Sendo assim, a questão proeminente é a seguinte: quando Aristóteles diz que as premissas da demonstração científica devem ser "imediatas", qual é o uso de "mediador" que ele tem em mente? Em 93b22 e 94a9, os "imediatos" parecem ser os itens para os quais não há nenhuma causa anterior, mas, por outro lado, alguém poderia argumentar que, em contextos como 84b22, "proposições imediatas" são aquelas que não podem ser provadas por um silogismo correto.

Como dissemos, uma proposição pode ser imediata no sentido de que é impossível explicar a relação entre seus termos por relações mais fundamentais que cada um tivesse com um termo mediador adequado. Mas uma proposição pode ser imediata no sentido de que é impossível deduzir ou provar formalmente a relação entre seus termos pelas relações que cada um tivesse com um termo mediador correto. Se uma proposição é imediata neste último sentido, ela também é imediata, a fortiori, no primeiro sentido - mas não vice-versa. E essa assimetria basta para ver que é perfeitamente possível que, ao dizer que as premissas da demonstração científica devem ser "proposições imediatas", Aristóteles queira dizer apenas que elas não podem ser explicadas apropriadamente por nenhuma causa anterior - deixando em aberto a possibilidade de haver uma dedução correta das mesmas. É claro que a interpretação axiomatizante não pode admitir esta última

27 Não precisamos dizer que Aristóteles introduz um novo sentido para "meson" nesses casos: a expressão ainda preserva seu núcleo básico de sentido, que é o de termo mediador pelo qual se estabelece uma relação entre dois termos extremos. No contexto do livro II dos Segundos Analíticos, no entanto, a expressão é usada para designar, mais estritamente, a causa pela qual a relação entre dois extremos se estabelece.

Manuscrito - Rev. Int. Fil., Campinas, v. 35, n. 1, p. 7-60, jan.-jun. 2012. 
alternativa. Mas, como veremos, parece ser essa a alternativa que Aristóteles tinha em mente.

Muitas vezes, nos Segundos Analíticos, Aristóteles deixa claro que, na demonstração científica, os termos maior e médio são coextensivos entre si. ${ }^{28}$ Sob essas condições extensionais, para qualquer termo menor, é possível provar reciprocamente a atribuição do maior e a do mediador. A premissa menor, nesse caso, pode ser corretamente deduzida se tomamos como antecedentes a conclusão e a conversão da premissa maior. Isso mostra que, se admitimos, com Aristóteles, a coextensão entre os termos mediador e maior no contexto de uma demonstração, é falso dizer que a premissa menor não pode ser deduzida em uma prova correta. Aristóteles mesmo nos dá um exemplo em 78a30-b4: dada a coextensão entre "estar próximo da Terra" e "não cintilar" (no domínio dos corpos celestes), pode-se provar ou bem que todo planeta está próximo da Terra ou bem que todo planeta é nãocintilante.

Alguém poderia objetar que a coextensão entre os termos maior e mediador não parece ser o caso-padrão nas demonstrações científicas. No entanto, essa objeção nada mais é senão preconceito sedimentado na tradição. Conhecer um fato pela sua causa é um dos traços proeminentes pelos quais Aristóteles define o conhecimento científico em 71b9-12. Ora, nos dois contextos mais relevantes em que Aristóteles procura lapidar de modo mais nítido a noção de causalidade pressuposta em sua definição de conhecimento científico, ele insiste na coextensão entre a "causa" (na estrutura silogística, o termo mediador) e o "causado" (o termo maior), bem como deixa claro que a causa primeira se exprime como um termo mediador que é coextensivo com o termo maior e que se impõe, portanto, como condição suficiente e

${ }^{28}$ Cf. 78b13-28; 98a35ss. (especialmente 98b35-36). Explorei esse ponto mais detidamente em "Aristotle's notion of cause in Posterior Analytics A.13", paper apresentado em Coimbra em 2011.

Manuscrito - Rev. Int. Fil., Campinas, v. 35, n. 1, p. 7-60, jan.-jun. 2012. 
necessária para a atribuição do maior a um dado sujeito. ${ }^{29} \mathrm{Se} \mathrm{B}$ é a causa primeira de $\mathrm{A}$, então atribuir $\mathrm{B}$ a um dado sujeito $\mathrm{C}$ é não apenas condição suficiente mas também condição necessária para atribuir A ao sujeito C.

Essa ênfase na coextensão também é clara no conceito central que muitos, apressadamente, declaram ser anômalo e confinado às idiossincrasias dos Segundos Analíticos: o conceito de "universal comensurado", que Aristóteles introduz em 73b26ss. ${ }^{30}$ Aliás, esse contexto deixa ainda mais claro o ponto que queremos ressaltar, pois Aristóteles exige que até mesmo o termo menor seja coextensivo com o maior - exige que se encontre o domínio exato, isto é, coextensivo, de aplicação de um dado atributo (73b39-74a3). Ora, se os três termos da demonstração são co-extensivos, é ainda mais claro que qualquer uma das três proposições da demonstração pode ser deduzida pelas relações entre os mesmos termos. E Aristóteles tinha plena ciência disso: a prova silogística dessa dedutibilidade é dada em Primeiros Analíticos $57 \mathrm{~b} 18-58 \mathrm{a} 20 .{ }^{31}$

Impõe-se, assim, a convicção de que as premissas da demonstração científica devem ser "imediatas" no sentido de não poderem ser explicadas adequadamente por nenhuma causa anterior, e não no sentido meramente formal de não poderem ser deduzidas por nenhum argumento correto. É irrelevante, na caracterização das

${ }^{29}$ Segundos Analíticos I-13 (especialmente 78b13-28) e II-16 (especialmente 98b4-5, 35-36).

${ }^{30}$ Cf. Ross (1949, p. 523): "this strict sense of katholou is, perhaps, found nowhere else in Aristotle"; Barnes (1993, p. 118), afirma que se trata de um "sentido singular" do termo. Porchat (2000, p. 157-161), mostra muito bem a compatibilidade e mesmo harmonia entre os diversos usos de "katholou".

${ }^{31}$ Cf. também Segundos Analíticos 73a12-14.

Manuscrito - Rev. Int. Fil., Campinas, v. 35, n. 1, p. 7-60, jan.-jun. 2012. 
premissas como "imediatas", a possibilidade de as deduzir corretamente como conclusão de um silogismo. ${ }^{32}$

Além do mais, outros fatores convergem para mostrar que o sentido de "primeiras" e "imediatas" que Aristóteles tem em vista em 71b20-33 diz respeito a relações explanatórias e não a relações meramente formais ou a características epistemológicas. Em 72a5-6, Aristóteles elucida que os "primeiros" dos quais depende e procede a demonstração são "princípios adequados". Em 74b24-26, há uma associação estrita entre o "primeiro do gênero" sobre o qual se demonstra e a noção de "adequado". Esta última noção deve ser compreendida à luz do que Aristóteles diz em Segundos Analíticos I-9. Discutiremos o ponto com mais detalhe na seção VII: princípios adequados - os quais, a rigor, são os únicos que garantem que se tem conhecimento científico de dada proposição - são os princípios que se atribuem ao sujeito enquanto ele é ele mesmo, ou seja, enquanto ele é tomado sob a descrição essencial que é relevante para explicar por que ele tem o atributo que se quer explicar.

Cumpre notar, finalmente, que, se entendemos "primeiras" e "imediatas" no sentido que estamos a propor, os requisitos que Aristóteles impõe às premissas da demonstração científica se tornam bem mais articulados à definição de conhecimento científico dada em 71b9-12. Seria muito tortuoso (e não caberia nos limites desse artigo) mostrar a conexão entre, de um lado, ser primeiro e imediato e, de outro, a noção de necessidade (como se evidencia em 75b24-26). Falarei algo sobre essa conexão mais adiante, mas, nos limites deste artigo, meu foco principal consistirá na conexão entre os requisitos em questão e a noção de causa. Isso me leva à discussão do requisito seguinte.

32 Pelas razões alegadas, discordamos totalmente de Smith (2009, p. 53-4), que julga que proposições imediatas são aquelas que "cannot be deduced from any other true propositions".

Manuscrito - Rev. Int. Fil., Campinas, v. 35, n. 1, p. 7-60, jan.-jun. 2012. 


\section{Premissas como causa da conclusão}

$\mathrm{Na}$ primeira enunciação dos seis requisitos, em 71b20-22, a noção de causa aparece por último. No entanto, ao retomar os seis requisitos no intuito de justificá-los, em 71b29-30, a noção de causa aparece em quarto lugar. Essa mudança de posição não parece ser sem motivos. Aristóteles justifica o requisito de ser causa pela definição de conhecimento científico dada em 71b9-12, a qual é explicitamente retomada em 71b30-31. E tal requisito parece dominar o sentido dos dois requisitos restantes, ${ }^{33}$ como veremos: não apenas a noção de anterioridade ou prioridade é concebida em termos de prioridade causal, mas também a noção de "mais conhecido" acaba, em última instância, por depender da noção de causa (ou mesmo se dissolver na noção de causa).

Mas o que significa dizer que as premissas devem ser causa da conclusão? Há um sentido trivial em que se pode dizer que as premissas são causa da conclusão em qualquer silogismo correto. ${ }^{34}$ Ao apresentarem as propriedades formais apropriadas, as premissas acarretam a conclusão. Mas Aristóteles obviamente não estaria satisfeito como essa interpretação puramente lógica da noção de causa.

33 Para opinião semelhante à nossa, ver Ross (1949, p. 509); Porchat (2000, p. 100). Para intepretação oposta, ver Barnes (1993, p. 95-6).

${ }^{34}$ Cf. Temístio 5.17-21. Barnes (1993, p. 95), é inaceitavelmente obsuro a esse respeito: "If the only knowledge necessary for having a demonstration of $\mathrm{P}$ is knowledge of the principles from which $\mathrm{P}$ is deducible, then the principles must contain the explanation of P" (grifo meu). Barnes não deixa claro se, no seu entendimento, Aristóteles aceita o antecedente deste condicional, mas, por isso mesmo, sugere que Aristóteles tenha sido ingênuo o bastante para propor a tese ridícula (na qual "must" soa como um wishfull thinking) de que princípios suficientes para deduzir $\mathrm{P}$ (de modo correto) seriam os princípios que dão a explicação causal de P. Nada está mais distante da teoria aristotélica. Para uma visão diferente da de Barnes, ver Kosman (1973), Burnyeat (1981, p. 101, 108-115) e McKirahan (1992, p. 23).

Manuscrito - Rev. Int. Fil., Campinas, v. 35, n. 1, p. 7-60, jan.-jun. 2012. 
O requisito da causalidade deve ser tomado de modo mais específico: em uma demonstração científica, as premissas devem apresentar, como termo mediador, a causa apropriada que faz o sujeito $\mathrm{C}$ ter a propriedade A e, portanto, explica adequadamente o fato relatado na conclusão. A mera verdade das premissas, somada à forma lógica de um argumento válido, não é suficiente para explicar adequadamente a conclusão.

Considere-se, por exemplo, a proposição "todos os seres humanos são mortais". Essa proposição pode ser conclusão de vários silogismos corretos em Barbara. Ela seria bem deduzida se tomássemos como mediador o termo "animal" ("Todos os seres humanos são animais; todos os animais são mortais; logo, todos os seres humanos são mortais"). No entanto, sua verdade seria igualmente bem estabelecida pelo silogismo que tomasse como mediador o termo "mamífero" ("Todos os seres humanos são mamíferos; todos os mamíferos são mortais; logo, todos os seres humanos são mortais"), bem como pelo silogismo que tomasse como mediador o termo "ser vivo sublunar" ("Todos os seres humanos são seres vivos sublunares; todos os seres vivos sublunares são mortais; logo, todos os seres humanos são mortais"), ou o termo "animal bípede", ou o termo “animal racional" etc. Diante dessa proliferação de silogismos corretos - todos eles igualmente capazes de estabelecer que a conclusão é verdadeira - surgem as questões decisivas: todos eles captariam a causa adequada do fato reportado na conclusão? Todos eles poderiam ser considerados como demonstrações científicas da mesma proposição?

A resposta de Aristóteles a essas duas questões é negativa. Todos os silogismos propostos no parágrafo anterior fornecem alguma explicação para o fato relatado na conclusão e, portanto, captam certa causa do que se relata na conclusão. Mas isso não basta para alcançar uma demonstração científica. Para que se tenha uma demonstração científica, o termo mediador deve captar a causa adequada ou a causa 
primeira do fato apresentado na conclusão. ${ }^{35}$ Aristóteles não oferece nenhuma definição dessa noção mais estrita de causa primeira, mas ele é claro o suficiente a respeito de algumas de suas características básicas. A noção de causa adequada se circunscreve por uma característica extensional bem clara: como termo (B) atribuído ao sujeito (C) da predicação assumida como explanandum, a causa adequada deve ser coextensiva com o atributo (A) a ser explicado. Aristóteles é bem claro a esse respeito na seguinte passagem:

"por que a parede $[\mathrm{C}]$ não respira $[\mathrm{A}]$ ? Porque não é animal $[\mathrm{B}]$. Mas, se isto [sc. não ser B] fosse causa do não respirar [= não ser A], seria preciso que o animal $[\mathrm{B}]$ fosse causa do respirar [A] - isto é, se sua negação $[=$ não ser $\mathrm{B}]$ fosse causa do não ser o caso [= não ser $\mathrm{A}]$, a afirmação $[=$ ser B] seria causa do ser o caso [= ser A]. [...] Mas, no que respeita aos termos assim relacionados, não se satisfaz o [requisito] mencionado: não é todo animal que respira" (78b15-23).

Nessa passagem, longe de divagar a respeito de propriedades que deveriam ser satisfeitas por toda e qualquer causa ${ }^{36}$ (ou por todo e

35 Mignucci (2007, p. 179), nota o problema: "la sua intuizione è che di un certo stato di cose $\mathrm{P}$ talvolta sono possibili spiegazioni $\mathrm{S}_{1}$ ed $\mathrm{S}_{2}$ che abbiano un diverso grado di pertinenza e genericità. Se $S_{1}$ è tale che, appunto per la sua generacità è applicabile anche ad uno stato di cose $\mathrm{Q}$ molto diverso da $\mathrm{P}$, mentre $S_{2}$ vale solo por $P$, allora $S_{2}$ è da privilegiare rispetto a $S_{1}$ allorché sia in questione la spiegazione scientifica di P". No entanto, Mignucci parece julgar que o critério para discernir qual é a explicação mais apropriada seria apenas extensional.

36 Barnes (1993, p. 157), atribui erradamente a Aristóteles a pretensão de descrever um "princípio" que fosse válido para todas as explicações negativas de conclusões negativas. Mignucci (2007, p. 197) confessa não entender o ponto, mas claramente viu que Aristóteles tenta relacionar a noção de causa (adequada) com a noção de condição suficiente e necessária (cf. Pellegrin (2005, p. 197)). Porchat (2000, p. 96), compreende bem o ponto de Aristóteles: "se a negação do médio (...) fosse a causa real de elas não respirarem etc." (grifos meus). Mas Porchat não enfatiza que Aristóteles está a empregar, nessa passagem, um requisito que estabelece as características extensionais de toda

Manuscrito - Rev. Int. Fil., Campinas, v. 35, n. 1, p. 7-60, jan.-jun. 2012. 
qualquer mediador de um silogismo correto), Aristóteles expõe um requisito extensional para a noção de causa primeira: para ser primeira, uma causa deve ser não apenas condição suficiente, mas também condição necessária para a atribuição da propriedade ao sujeito em pauta. Consideremos o exemplo anterior, no qual a proposição "todos os seres humanos são mortais" fora tomada como explanandum. A causa primeira deverá ser um termo mediador que satisfaça conjuntamente as duas exigências seguintes: (i) sua atribuição ao menor deve ser condição suficiente para atribuir o maior ao menor ("se todos os seres humanos são B, segue-se que todos os seres humanos são mortais"), (ii) sua atribuição ao menor deve ser condição também necessária para atribuir o maior ao menor (se "todos os seres humanos são B" fosse uma predicação falsa, também seria falsa a conclusão "todos os seres humanos são mortais"). A exigência (i) é formulável como um Barbara. Já a exigência (ii) pode ser formulada em Camestres, com a conversão da premissa maior do Barbara: "todos os mortais são B". A conjunção entre (i) e (ii) demarca a exigência de que o atributo explanandum A e sua causa primeira B sejam coextensivos. ${ }^{37}$

A noção de causa primeira ou causa adequada também requer algumas características intensionais. No entanto, o esclarecimento mais razoável que Aristóteles nos dá a respeito dessa noção provém dos exemplos. "Não cintilar" e "estar próximo da Terra" são termos coextensivos para o domínio dos corpos celestes e, por isso, podemos provar "um pelo outro", em relação a um mesmo sujeito, como os planetas. No entanto, há uma assimetria causal entre os termos: não é "porque não cintilam que os planetas estão próximos da Terra", mas é

causa primeira (ou causa real, como ele diz), para além dos requisitos menos exigentes que se aplicam a toda e qualquer causa.

37 Cf. McKirahan (1992, p. 214). Aristóteles defende o mesmo ponto com algum detalhe em Segundos Analíticos II 16 (cf. especialmente 98b35-36).

Manuscrito - Rev. Int. Fil., Campinas, v. 35, n. 1, p. 7-60, jan.-jun. 2012. 
"porque estão próximos da Terra que os planetas não cintilam" (78a3637). ${ }^{38}$

Em Segundos Analíticos I-9, Aristóteles não usa a expressão "causa adequada" ou "causa primeira", mas julgamos que os "princípios de cada coisa, enquanto ela é o que essencialmente é", equivalem exatamente à noção de causa adequada ou causa primeira. Falarei desses princípios na seção VII deste artigo. Convém ainda sublinhar dois pontos de extrema relevância, que também serão mais bem explorados na seção VII. Primeiro: é essa noção de causa adequada que está envolvida na definição de conhecimento científico em 71b9-12. Segundo: é essa noção de causa que constitui a motivação última de Aristóteles para propor a silogística como instrumento formal de demonstração científica. A causa é concebida de acordo com a estrutura triádica da primeira figura silogística: a causa é "captada" ou "expressa" como um termo mediador, B, o qual, atribuído ao sujeito em pauta, C, faz tal sujeito ter a propriedade A, cuja atribuição ao sujeito é o se quer explicar. ${ }^{39}$

\section{Premissas anteriores}

“Anterior" se diz em vários sentidos no jargão aristotélico. ${ }^{40}$ Dois sentidos são proeminentes para compreender o requisito da prioridade no contexto em questão: a prioridade (ou anterioridade) causal e certa prioridade que poderíamos chamar de lógica. Aristóteles não é muito claro a respeito de uma eventual prioridade lógica. Ele reconhece um sentido de "anterior" que se capta, em geral, pela assimetria nas relações de instanciação de predicados (e, conseqüentemente, nas relações entre condições de verdade de sentenças predicativas), bem como na assimetria entre as condições de

\footnotetext{
${ }^{38}$ Ver compreensão similar do ponto em McKirahan (1992, p. 216).

${ }^{39}$ Ver Segundos Analíticos 90a5-11; 93a30ss.; 98b5ss. Charles (2000, p. 37).

${ }^{40}$ Cf. Metafísica V 11 e Categorias 12.
} 
existência de dois (ou mais) seres. Começemos por este último caso, tomando como exemplo o sol e as plantas: se o sol não existisse, as plantas tampouco poderiam existir; mas, se as plantas não existissem, o sol poderia existir "separadamente das plantas". A este teste, que parece ter sido concebido em ambiente platônico, podemos chamar "sunanairesis" ou "co-destruição". ${ }^{41} \mathrm{O}$ sol, ao sobreviver ao teste - isto é, ao existir separadamente das plantas, sem que a inversa seja o caso seria tido como "anterior" às plantas. A mesma assimetria se observa na instanciação de predicados e condições de verdade de predicações. Tomemos duas sentenças predicativas, "S é F" e "S é G". Ora, uma delas será anterior a outra se e somente se puder ser verdadeira "separadamente" da outra e a verdade da outra sempre implicar sua verdade. Assim, "S é F" é anterior a "S é G" quando as seguintes condições são conjuntamente satisfeitas: a verdade de "S é F" não acarreta a verdade de "S é G", mas a verdade de "S é G" acarreta a verdade de "S é F". Por exemplo, a verdade de "Sócrates é animal" não acarreta a verdade de "Sócrates é ser humano", mas a verdade de "Sócrates é ser humano" acarreta a verdade de "Sócrates é animal". Nessas condições, se diz que "S é animal" é anterior a "S é ser humano". 42

Mas isso consiste em identificar como "anterior" aquilo que desempenha a função de condição sine qua non para o "posterior": para um S qualquer, ser animal é condição sine que non para ser um ser

41 Este nome provém do uso que Categorias faz do verbo "synanairein" em 7b19ss. Em Metafísica 1019a2-4, esse mesmo teste para relações de prioridade é chamado de "prioridade segundo a natureza e a essência". Para abordagem diversa, ver Peramatzis (2011). Discordamos de Porchat (2000, p. 109-110), que julga que a anterioridade por natureza em APo 72a1-5 "corresponde, obviamente", à anterioridade segundo a natureza e a essência em Met. 1019a24.

42 Para esse tipo de prioridade, cf. Tópicos 141b3ss. e Metafísica, 1018b30-37 ("prioridade pelo conhecimento"). Tratei dos problemas envolvidos nesse assunto em Angioni (2010) e (2008, p. 60-75).

Manuscrito - Rev. Int. Fil., Campinas, v. 35, n. 1, p. 7-60, jan.-jun. 2012. 
humano, mas não é condição suficiente. No entanto, quando se fala da relação entre premissas e conclusão, seria de se esperar o inverso: dizer que "p, então q" é um argumento válido equivale a dizer que a verdade de p será condição suficiente para engendrar a verdade de q, ou, dito de outro modo, equivale a dizer que, ainda que q possa ser verdadeira sem que $\mathrm{p}$ seja verdadeira, $\mathrm{p}$ não pode ser verdadeira sem que q seja também verdadeira. Essa relação de prioridade entre premissas e conclusão de um argumento válido pode, eventualmente, ser chamada de prioridade lógica, e muitos se sentiriam tentados a dizer que é esse tipo de prioridade que Aristóteles tem em vista, quando diz que as premissas da demonstração científica devem ser anteriores à conclusão.

No entanto, há duas fortes razões para rejeitar essa interpretação. A primeira razão é que o requisito da "prioridade", como todos os demais requisitos listados em 71b 20-22, é entendido como condição sine que non para a demonstração, não para qualquer silogismo (muito menos para qualquer argumento correto). Trata-se de um requisito sem o qual poderia haver silogismo, mas não poderia haver demonstração (71b23-25) ${ }^{43}$. Se Aristóteles tivesse em vista a prioridade lógica acima caracterizada em termos de suficiência das premissas para $O$ acarretamento da conclusão, ele não poderia dizer que, sem esse requisito, poderia haver silogismo. De fato, "silogismo" é um termo usado por Aristóteles de tal modo que envolve a noção de argumento válido. ${ }^{44}$ Ainda que, em outros contextos, Aristóteles tenha empregado

${ }^{43}$ Alguém poderia objetar que, embora a satisfação conjunta dos seis requisitos não seja condição sine qua non para o silogismo, não se poderia inferir que cada requisito em separado também falha em ser condição sine qua non para o silogismo. No entanto, creio que a quantificação envolvida na sentença em 71b23-24 deve ser interpretada tanto conjuntivamente como também distributivamente: "pode haver silogismo sem a satisfação de nenhum desses requisitos".

44 Quando um argumento de forma silogística não atinge uma conclusão válida, Aristóteles não diz "este silogismo é inválido", mas diz "não haverá

Manuscrito - Rev. Int. Fil., Campinas, v. 35, n. 1, p. 7-60, jan.-jun. 2012. 
o termo "syllogismos" em acepção mais ampla, 45 é claro que, no contexto da teoria da demonstração nos Segundos Analíticos, o termo designa uma das formas de argumento válido envolvendo a relação entre três termos, de acordo com uma das figuras etc. Portanto, se pudesse haver silogismo mesmo sem a satisfação do requisito da "prioridade" entendido desse modo, poderia haver um silogismo no qual as premissas poderiam ser verdadeiras sem acarretar a verdade da conclusão, ou seja, um silogismo no qual a conclusão poderia ser falsa e as premissas, verdadeiras - o que é incompatível com o pressuposto de que todo silogismo, no sentido estrito do termo, é um argumento válido. Mesmo se Barnes tivesse razão na tese de que "syllogismos" designa uma dedução válida, teríamos o mesmo resultado indesejado.

A segunda razão é que, ao retomar os seis requisitos no intuito de justificá-los, Aristóteles sugere que o requisito da prioridade depende do requisito da causalidade: "devem ser anteriores, se precisamente são causas" (71b31). ${ }^{46}$ Isso quer dizer que o sentido relevante da

silogismo" (ouk estai syllogismos) ou algo equivalente. Cf. Primeiros Analíticos 26a31-32 ss.

45 Cf. Ethica Nicomachea 1142b23. Muitos intérpretes sustentam que "syllogismos" nos Tópicos não designa a noção estrita de silogismo (argumento em forma predicativa com três termos, conforme as "figuras" etc.). Não há nenhuma evidência, no entanto, para a proposta de Barnes (1981, p. 22-25), que afirmou que a noção de estrita de silogismo não teria termo grego correspondente (!) e "syllogimos" deveria ser traduzido como "deduction". Posição bem mais sensata é defendida por Striker (2009, p. 78-9), que restaurou a boa tradução de "syllogismos" por "syllogism".

${ }^{46}$ Cf. Burnyeat (1981, p. 127), e Porchat (2000, p. 102). Ross (1949, p. 509), vai mais longe e diz que os requisitos da causalidade e da prioridade são apenas modos diversos de dizer a mesma coisa. No entanto, Porchat (2000, p. 114, cf. 123-4), julga que a anterioridade causal de que fala Categorias 12 "reduz-se" à anterioridade "que não reciproca segundo a seqüência do ser" (p. 109), que equivale, como ele muito acertadamente defende, à anterioridade segundo a natureza e a essência, de que fala Metafísica 1019a2-4 e, em nosso vocabulário, equivale à anterioridade das condições sine quibus non. A proposta do referido

Manuscrito - Rev. Int. Fil., Campinas, v. 35, n. 1, p. 7-60, jan.-jun. 2012. 
prioridade, neste contexto, é governado pela noção de causalidade. Alguém poderia dizer, contra essa segunda razão, que a noção de causalidade poderia ser analisada em termos de conseqüência lógica. A causa, dir-se-ia, é tal que, ao ser o caso (ou vir a ser), faz necessariamente ser o caso também o efeito, do mesmo modo que as premissas de um argumento válido são tais que, sendo verdadeiras, necessariamente fazem ser verdadeira também a conclusão.

No entanto, em defesa de nossa interpretação, duas coisas devem ser ressaltadas. Ao caracterizar a noção de causa no contexto da demonstração científica, Aristóteles não se limita à característica acima ressaltada, segundo a qual a causa seria apenas suficiente para fazer o causado ser o caso. Como notamos na seção anterior deste artigo, Aristóteles insiste, várias vezes - e de modo consistente - que a causa primeira, que deve ser capturada na demonstração científica, não é apenas suficiente, mas também necessária para fazer o causado ser o caso. Isso se traduz, na estrutura silogística, na exigência de que os termos maior (explanandum) e mediador (explanans) sejam coextensivos entre si. ${ }^{47}$

A segunda coisa a ressaltar, em defesa de nossa interpretação, consiste no fato de Aristóteles ter reconhecido e destacado uma noção

autor está muito mal explicada, pois uma redução é tudo que Aristóteles não quer neste contexto. É claro que a prioridade da causa sobre o causado resgata a assimetria que fora perdida no "acompanhamento recíproco" entre causa e causado. No entanto, a assimetria na relação causal não se expressa em nenhuma assimetria quanto ao acompanhamento do ser o caso (tampouco se expressa em alguma assimetria lógica ou formal) e, por isso, não estamos autorizados a falar em "redução". A assimetria é uma característica comum a todos os tipos de prioridade e, por si só, não permite a redução de nenhum tipo específico a outro. Pior ainda: tudo que Aristóteles não quer, em APo I-2, é reduzir a prioridade causal à prioridade que caracteriza as condições sine quibus non - como Filopono, 25.11-16, parece ter percebido (um axioma pode ser condição sine qua non sem ser causa).

${ }^{47}$ Cf. Segundos Analíticos 98b35-36.

Manuscrito - Rev. Int. Fil., Campinas, v. 35, n. 1, p. 7-60, jan.-jun. 2012. 
específica de prioridade causal, que está longe de se reduzir a alguma assimetria logicamente formulável - quero dizer, está longe de poder ser captada logicamente por alguma assimetria entre as condições de verdade da causa e do causado. ${ }^{48} \mathrm{O}$ texto-chave, neste caso, é Categorias 12: "é anterior aquilo que não reciproca na implicação do 'ser o caso' (ten tou einai akolouthesin); por exemplo, o um é anterior ao dois, pois, se há dois, imediatamente segue-se que há um, mas, havendo um, não é necessário haver dois; de modo que, se partimos do um, a implicação do 'ser o caso o item restante' não reciproca, e julga-se que é anterior o item a partir do qual a implicação do 'ser o caso' não reciproca" (14a 29-35).

A relação entre a causa e o causado é, obviamente, assimétrica: se $\mathrm{B}$ é causa de $\mathrm{A}$, no sentido estrito requisitado pela teoria da demonstração, não se pode dizer que A seja igualmente causa de B. ${ }^{49}$ No entanto, essa assimetria causal não se faz acompanhar por nenhuma assimetria lógica nas relações de acarretamento entre a verdade de "B" (isto é, a atribuição verdadeira de B a um dado sujeito) e a verdade de "A" (a atribuição verdadeira de A a esse mesmo sujeito). Sendo B causa de A no sentido estrito, B e A se implicam mutuamente e, se forem

48 A opinião de Barnes (1993, p. 95), é ridícula: "he has in mind here not the curious 'explanatory' priority of Cat 12". Se Barnes julgou a noção de prioridade causal exposta em Cat. 12 como algo "curioso", não espanta que tenha entendido tão pouco sobre a teoria da demonstração. O que Barnes e outros procuram é algo que essa noção de prioridade torna impossível: assimetrias lógico-formais que exprimissem e acompanhassem a assimetria causal. Também discordamos de Porchat (2000, p. 119, 123-4), que estranhamente supõe que a anterioridade causal possa ser "reduzida" à anterioridade que se capta na assimetria entre as relações formais de acarretamento. Ver nota 45.

49 Em Física 195a8-11, Aristóteles diz que a causa eficiente e a final são "causas recíprocas", mas isso não afeta o meu ponto, pois cada uma delas não é causa no mesmo aspecto: exercícios físicos são causa eficiente pela qual a saúde vem a existir no corpo que se exercita; já a saúde é a causa final que torna os exercícios físicos desejáveis para um dado agente.

Manuscrito - Rev. Int. Fil., Campinas, v. 35, n. 1, p. 7-60, jan.-jun. 2012. 
interpretados como termos no silogismo (como de fato o são), são termos co-extensivos, referentes a propriedades distintas de um mesmo sujeito. Pode-se talvez lamentar que Aristóteles tenha concebido a noção de causa (ou ao menos a de causa primeira) nesses termos, que não se deixam captar por nenhuma assimetria nas relações lógicas entre causa e causado - sobretudo quando se confia à correção dos argumentos a tarefa mágica de captar o mais específico da demonstranção científica. No entanto, talvez essa seja uma das forças filosóficas da teoria de Aristóteles sobre a demonstração científica: a correção formal e semântica das deduções ainda não basta para explicar de modo relevante aquilo que se quer conhecer cientificamente.

Pode-se concluir, portanto, que a anterioridade ou prioridade, como requisito para as premissas da demonstração científica, consiste estritamente na prioridade causal, nos termos em que foi caracterizada acima.

\section{Premissas mais conhecidas}

Resta o requisito que aparece por último na ordem da justificação: as premissas devem ser "mais conhecidas" que a conclusão. Esse requisito parece dar azo a uma interpretação em termos epistemológicos e, sobretudo, em termos de axiomatização. Seriam "mais conhecidas" as premissas "mais evidentes" ou, em última instância, aquelas cujo sentido impõe a convicção de que são o caso. ${ }^{50}$ A discussão desse requisito, no entanto, não é muito clara no texto de Aristóteles. Em 71b31-32, ele emprega outra expressão, “ser

${ }^{50}$ Cf. Scholz (1975, p. 56): “Aristotle's formula 'the assertion that $\mathrm{p}$ is more knowable than the assertion that q' means the same as 'the truth of $\mathrm{p}$ is more certainly knowable than the truth of q' or 'p is more evident than $q$ ". Tal interpretação encontra apoio em Filopono 25.3-5, que interpreta "gnorimon" em termos de "autopiston" (aquilo que por si mesmo se impõe à nossa convicção como verdadeiro).

Manuscrito - Rev. Int. Fil., Campinas, v. 35, n. 1, p. 7-60, jan.-jun. 2012. 
previamente conhecido" (proginoskomena), e, sem discutir se essa nova expressão equivale à primeira ("ser mais conhecido", gnorimotera), afirma que as premissas devem ser "previamente conhecidas" nos dois modos em que esta expressão é usada: um modo diz respeito à mera compreensão dos termos, outro diz respeito ao reconhecimento de que é o caso. Não é muito claro se é relevante ou não que o sentido das premissas seja compreendido previamente ao sentido da conclusão. ${ }^{51}$ Mas é bem claro que se deve saber, previamente, que as premissas são o caso, se queremos atribuir-lhes o papel de princípio mediante o qual se deduz que a conclusão é o caso (ou até mesmo se lhe atribuímos o papel de princípio mediante o qual se explica por que a conclusão é o caso). Talvez o que Aristóteles queira dizer é que, ao formular uma demonstração, não basta apenas compreender o sentido das premissas (requisito que, no entanto, seria suficiente para a compreensão de que um argumento é válido), pois se deve também saber que elas são o caso. Se isso está correto, Aristóteles apenas afirmou que, na demonstração, é preciso saber que as premissas são verdadeiras - mas isso ainda não esclarece em que sentido as premissas seriam "mais conhecidas" que a conclusão. Se julgássemos que a tarefa essencial da demonstração científica é estabelecer que são verdadeiras certas proposições antes problemáticas, estaríamos satisfeitos como essa elucidação. Diríamos que aquela proposição que figura na conclusão tem seu valor de verdade indeterminado antes da prova demonstrativa, e esta última, ao deduzi-la de premissas verdadeiras, decide seu valor de verdade e o ampara na verdade das premissas. Assim, uma premissa seria "mais conhecida" que a conclusão porque seu valor de verdade, longe de ser problemático, estaria já determinado: e a verdade das premissas seria justamente o fator que permitiria deduzir (e decidir) que também é verdadeira a conclusão. Além do mais, uma interpretação axiomatizante poderia dar um passo a mais e dizer que Aristóteles, ao

51 Em 76a32-33, Aristóteles parece dizer que ambos os sentidos são "assumidos", e nada diz sobre a relação de prioridade entre eles.

Manuscrito - Rev. Int. Fil., Campinas, v. 35, n. 1, p. 7-60, jan.-jun. 2012. 
afirmar que as premissas devem ser mais conhecidas que a conclusão em ambos os sentidos, quer dizer que, para as premissas, a mera compreensão de seu sentido garante o conhecimento de que elas são o caso. ${ }^{52}$

Há grande risco de confusão, no entanto. E não parece haver evidência textual em favor das interpretações epistemologizantes e axiomatizantes. Como já assinalei, em 71b31-33, Aristóteles elucida em que sentido as premissas são (ou devem ser) previamente conhecidas. No entanto, o requisito em questão fora anunciado, em $71 \mathrm{~b} 21$ (cf. 71b29), em termos de "ser mais conhecidas que a conclusão" (gnorimotera), e não "conhecidas previamente à conclusão" (progignoskomena). Que a elucidação sobre "progignoskomena” seja aplicável também a "gnorimotera" é algo que carece de argumento e que não pode ser assumido como garantido. ${ }^{53}$ Além do mais, embora se possa intepretar a noção de "previamente conhecido" ("progignoskomena") em termos epistemológicos, relativos à convicção que temos sobre a verdade das premissas (cf. 72a32-37), nada garante que a noção de "mais conhecido" ("gnorimotera") também possa ser intepretada na mesma chave. Como veremos logo mais, o próprio Aristóteles parece reconhecer, em 72a27-29, que a exigência de conhecer previamente as premissas (no sentido de ter convicção prévia de que elas são verdadeiras) ainda não explica em que sentido ou por que elas são também mais conhecidas que a conclusão.

Em 71b33-72a5, Aristóteles acrescenta uma elucidação a respeito de dois sentidos de "mais conhecido" e "anterior", e se poderia argumentar que ele o faz justamente porque a noção de "mais conhecido" relevante no contexto não foi, ainda, perfeitamente esclarecida. ${ }^{54}$ Nesse sentido, se poderia julgar que, agora, Aristóteles se

52 Cf. Scholz (1975, p. 56-58).

53 Cf. Porchat (2000, p. 103).

${ }^{54}$ Discordamos de Barnes (1993, p. 96): "Aristotle plainly treats priority (in the relevant sense) and greater familiarity as one and the same thing". Cf. Taylor

Manuscrito - Rev. Int. Fil., Campinas, v. 35, n. 1, p. 7-60, jan.-jun. 2012. 
propõe a esclarecê-la em termos de prioridade: as coisas podem ser mais conhecidas ou para nós ou por natureza (sem mais), assim como podem ser "anteriores" ou para nós ou por natureza, e o sentido relevante para as premissas da demonstração científica seria o segundo. ${ }^{55}$ No entanto, essa elucidação nem sequer tenta especificar os traços conceituais da noção de "mais conhecido por natureza" (ou da noção de "anterior por natureza") ${ }^{56}$. Aristóteles apenas identifica extensionalmente quais itens contam como mais conhecidos "por natureza": os mais afastados da sensação ${ }^{57}$.

Mas Aristóteles volta a falar dessa característica das premissas de modo bem mais elucidativo, em 72a25-39. ${ }^{58}$ Embora a expressão "mais conhecidas" (gnorimotera) não ocorra literalmente nesse trecho, é óbvio que o uso do advérbio "mais" ("mallon”) em 72a28 se aplica ao

(1990, p. 121). McKirahan (1992, p. 30-31), sugere a mesma tese, mas logo depois argumenta que esses dois requisitos "need not be identical. They may be notionally distinct, while applying to the same items" (p. 31).

${ }^{55}$ É claro - como bem observa McKirahan (1992, p. 32) - que os princípios são "anteriores" em vários sentidos: em certa ordem temporal (ainda que não a da descoberta), do ponto de vista epistemológico, do ponto de vista causal, do ponto de vista lógico etc. A questão, porém, é discernir qual é o sentido relevante neste contexto da teoria. A mera associação entre "anterior" e "mais conhecido" não prova que se trata da "prioridade no conhecimento" (como quer Barnes (1993, p. 96)). Também não podemos ser levados pelas semelhanças extrínsecas das expressões e julgar que a noção de "anterior por natureza" (physei) equivale à noção de "anterior em natureza e em essência" (kata ten physin kai ten ousian) exposta em Metafísica 1019a2-4. Ver nota 45 supra.

${ }^{56}$ Cf. McKirahan (1992, p. 30-31).

${ }^{57}$ Quais são esses itens "mais afastados da sensação", tampouco é fácil de determinar, e é ingênuo assumir que se trata dos universais de maior generalidade, como "ser". Escrevi sobre o assunto em Angioni (2001).

${ }^{58}$ Barnes (1993), p. 96, julga que 72a25-b3 não oferece nenhuma justificação para aquilo que ele toma como "more familiar by nature" - mas é dele, não de Aristóteles, a confusão entre a noção de "maior familiaridade" e a noção de "conhecer mais". Ver, na direção que propomos, Porchat (2000, p. 103).

Manuscrito - Rev. Int. Fil., Campinas, v. 35, n. 1, p. 7-60, jan.-jun. 2012. 
verbo "conhecer" ("gignoskein”) e introduz, portanto, a mesma noção de "mais conhecido". ${ }^{59}$ Aristóteles ressalta que não basta dizer que as premissas têm de ser conhecidas previamente à conclusão, nem basta dizer que devemos ter mais confiança na verdade das premissas do que na verdade da conclusão. Aristóteles acrescenta que é preciso, também, conhecer as premissas mais do que a conclusão. Para elucidar em que sentido se diz que conhecemos uma proposição mais do que outra, Aristóteles evoca a estrutura triádica da causalidade. Suponha-se que o sujeito $\mathrm{C}$ tem a propriedade $\mathrm{A}$, e que o item $\mathrm{B}$ seja a causa pela qual $\mathrm{C}$ tem a propriedade A. Aristóteles parece afirmar que, neste caso, B é mais A do que C o é. Em outras palavras: a propriedade de ser A se aplica a B com mais pertinência (ou com "mais direito") do que a C, se $\mathrm{B}$ é a causa que faz $\mathrm{C}$ ter a propriedade $\mathrm{A}$. Se o fogo é a causa pela qual um corpo é quente, então o fogo é mais quente, ou é mais pertinentemente designado como algo quente. Esse arrazoado parece bem estranho, pois a pretensão que Aristóteles avança parece ser pertinente apenas a alguns casos específicos - propriedades físicas que admitem variação de grau. Pode-se compreender, por exemplo, a pretensão de que o fogo seja mais quente do que a chaleira que ele esquenta. Ainda que não aceitemos a verdade dessa pretensão, podemos compreender o que ela quer dizer. No entanto, é claro que Aristóteles não pode querer dizer que a proposição "esta chaleira é quente" tem menos valor de verdade (no instante em que é verdadeira) do que a proposição "o fogo é quente". ${ }^{60}$ O que Aristóteles pretende dizer é outra coisa.

59 O termo comparativo "gnorimoteron" ("mais conhecido") é elucidado na medida em que se elucida o que se quer dizer quando se fala em "mallon gignoskein" (“conhecer mais"). Cf. "mallon gnorizein” em 72a38-39.

${ }^{60}$ De nada adiantaria dizer que a primeira seria verdadeira apenas em alguns instantes, ao passo que a segunda seria verdadeira sempre, pois Aristóteles não parece admitir que uma entidade singular e contingente como esta chaleira pudesse ter, enquanto singular e contingente, propriedades suscetíveis de demonstração científica.

Manuscrito - Rev. Int. Fil., Campinas, v. 35, n. 1, p. 7-60, jan.-jun. 2012. 
De fato, Aristóteles não quer dizer que, se B é causa pela qual C é $A$, então $B$ é mais $A$. Essa tese se prestaria às objeções mais triviais o vinho (B) é causa pela qual o homem (C) fica bêbado (A), de modo que o vinho (B) deveria ser mais bêbado (A) que o homem. ${ }^{61}$ Aristóteles parece pressupor uma restrição de domínio: o recurso à noção de causa para dizer que um dos itens é "mais A" que outro pressupõe que o predicado A possa ser corretamente aplicado a ambos os itens: tanto C como B devem estar no "domínio de aplicação" do predicado A. ${ }^{62}$ Sob essa pressuposição, Aristóteles aplica seu esquema triádico às noções envolvidas na teoria da demonstração. É como se o termo "conclusão" (ou "os posteriores") assumisse o lugar do termo C, o predicado "ser conhecido" assumisse o lugar do termo A e, finalmente, o termo "premissas" (ou "os primeiros") ${ }^{63}$ assumisse o lugar do termo B: tal como o fogo é a causa que faz esta chaleira ser quente, do mesmo modo, as premissas funcionam como causa que faz a conclusão ser conhecida. ${ }^{64}$

Este ponto é extremamente ambíguo, porém. Dizer que as premissas são causa pela qual a conclusão é conhecida pode se encaixar em dois contextos bem distintos. O primeiro contexto seria aquele em que o valor de verdade de uma proposição (que será a conclusão da

61 Este exemplo, bem como outros igualmente pertinentes, provém de Filopono 38.4-9.

62 Filopono, 38.9-18, parece propor essa solução, mas logo depois (38.18-39.4) a rejeita por uma razão impertinente: julga que o argumento de Aristóteles teria de provar que as premissas são não apenas (i) mais conhecidas que a conclusão, mas também (ii) conhecidas previamente à conclusão, mas pressupor que C é A parece contrariar (ii). No entanto, não é preciso pressupor que $\mathrm{C}$ é A: basta pressupor que A possa ser corretamente atribuído a C.

63 O uso de "primeiros" (ta prota) em 72a28 sugere, também, que as premissas são chamadas de "primeiras" devido a esse papel causal.

${ }^{64}$ Cf. Porchat (2000, p. 103): "por que razão deverão as premissas ser mais conhecidas, senão em razão de sua mesma função causal?”.

Manuscrito - Rev. Int. Fil., Campinas, v. 35, n. 1, p. 7-60, jan.-jun. 2012. 
demonstração) é problemático e precisa ser decidido: não sabemos ainda (antes de encontrar as premissas) se tal proposição é verdadeira ou falsa, ou sabemos, mas não com a certeza que seria conveniente. Assim, para resolver o problema e decidir (ou certificar) que a proposição é verdadeira, buscamos outras proposições verdadeiras que, em virtude da mera forma lógica com que são arranjadas em um argumento, acarretariam a verdade da proposição em questão (que se torna, assim, conclusão de um argumento correto). Nesse caso, uma vez construído o argumento correto, poderíamos dizer que sabemos que a conclusão é verdadeira porque sabemos que as premissas são verdadeiras (e reconhecemos que o argumento é válido): as premissas seriam aquilo "pelo que" a conclusão se torna conhecida. ${ }^{65}$

Outro contexto, no entanto, seria aquele em que não mais está em questão (ou em dúvida) o valor de verdade da proposição que figurará como conclusão. Sabemos, de fato, que tal proposição é verdadeira. Não precisamos de nenhum argumento correto, com premissas verdadeiras, para nos assegurar de que tal proposição é verdadeira. O que queremos saber é por que ela é verdadeira. Em outras palavras, buscamos saber a causa apropriada que faz essa proposição ser verdadeira. Uma vez encontrada essa causa, ela poderá ser expressa nas premissas. As premissas, nesse caso, exprimem aquilo "pelo que" a conclusão é verdadeira. Ora, se conhecer cientificamente uma certa proposição (como "todos os humanos são mortais") é não apenas saber que ela é verdadeira, mas saber qual é a causa apropriada que a faz verdadeira (por exemplo, o fato de todos os humanos serem viventes de um certo tipo), e se são as premissas que exprimem essa causa apropriada, então, se pode dizer que as premissas são aquilo

${ }^{65}$ Barnes (1993, p. 96), parece favorecer essa opção, pois, de outro modo, não poderia ter dito que "in order to come to know something on the basis of a demonstration, we must already have a grasp of the principles which is better than the grasp which we are about to acquire of the conclusion" (grifos meus).

Manuscrito - Rev. Int. Fil., Campinas, v. 35, n. 1, p. 7-60, jan.-jun. 2012. 
"pelo que" a conclusão se torna "conhecida" (isto é, conhecida cientificamente). ${ }^{66}$

A questão decisiva, neste caso, é saber qual dos dois contextos acima descritos é favorecido por Aristóteles em sua teoria da demonstração e, conseqüentemente, qual dos dois contextos ele pressupõe ao elucidar o requisito de que as premissas devem ser mais conhecidas que a conclusão. Afirmo que o contexto paradigmático, para a noção aristotélica de demonstração científica, é o segundo: à demonstração, compete explicar pelas causas apropriadas por que é verdadeira uma conclusão que já era reconhecida como verdadeira. A tarefa central atribuída à demonstração não consiste em estabelecer, por premissas verdadeiras, que é verdadeira uma conclusão cujo valor de verdade era antes problemático ou dubitável. ${ }^{67}$

É claro que, em 72a25-b4, Aristóteles insiste em certas características epistemológicas do conhecimento científico. Ele diz claramente que, se conhecemos a conclusão pelas premissas, devemos ter mais confiança na verdade das premissas etc. Aristóteles adiciona algo ainda mais forte nas linhas finais do capítulo: quem tem conhecimento científico, sem mais, não deve ser suscetível à disuassão (72b3-4). Nada lhe seria mais certo do que os princípios que são opostos às premissas das quais se poderia deduzir o "erro contrário" (72b1-3). Não estou a negar que considerações epistemológicas desse teor também tenham seu lugar na teoria da demonstração científica. Minha proposta é, porém, que esses requisitos epistemológicos não

66 Cf. McKirahan (1992, p. 32): "we may know the truth of a derivative proposition before we know the principles, but we cannot know that proposition scientifically until we have appropriate knowledge of the principles". Filopono, 40.15-17, parece assumir essa opção, mas seu argumento não nota que a expressão "conhecer a conclusão [q]" é ambígua entre (i) reconhecer que a proposição q é verdadeira, (ii) saber que a proposição q é a conclusão de um argumento correto e, portanto, não pode não ser verdadeira se as premissas desse argumento são verdadeiras.

${ }^{67}$ Cf. Burnyeat (1981, p. 101, 137).

Manuscrito - Rev. Int. Fil., Campinas, v. 35, n. 1, p. 7-60, jan.-jun. 2012. 
encontram lugar entre os seis requisitos das premissas, listados em 71b20-22. Em 72a25-b4, Aristóteles apresenta três pretensões:

(i) quem tem conhecimento científico deve ter mais confiança na verdade das premissas do que na verdade da conclusão;

(ii) quem tem conhecimento científico deve conhecer as premissas mais do que a conclusão;

(iii) quem tem conhecimento científico deve ter a confiança máxima nos princípios que são opostos àqueles dos quais se deduziria $\mathrm{o}$ erro contrário.

O ponto (iii) pode ser tomado como uma exploração superlativa do ponto (i). Não obstante, leitura meticulosa do capítulo mostra que Aristóteles não confunde os pontos (i) e (ii) como se fossem um só, tampouco sugere que o ponto (i) seria suficiente para o ponto (ii). Ao contrário, por duas vezes, Aristóteles afirma que os pontos (i) e (ii) devem ser somados: não basta ter mais confiança na verdade das premissas, é preciso, adicionalmente, conhecê-las mais - e "conhecer as premissas mais do que a conclusão" foi elucidado em termos de causalidade: é por serem causa que as premissas devem ser descritas como mais conhecidas. ${ }^{68} \mathrm{O}$ último requisito elucidado por Aristóteles, portanto, novamente se relaciona à noção básica de causalidade.

\section{Princípios adequados (oikeiai archai)}

O passo seguinte consiste em explorar certas considerações tecidas por Aristóteles sobre o conjunto dos seis requisitos. Em 71b 22 23, Aristóteles afirma que "deste modo [sc. quando os seis requisitos são conjuntamente satisfeitos], os princípios serão adequados ao que se quer mostrar ou provar". E acrescenta que tais requisitos não são necessários para um silogismo qualquer - pois se pode engendrar um silogismo válido sem atender a nenhum desses requisitos, assim como

${ }^{68}$ Para arrazoado semelhante ao nosso, ver Burnyeat (1981, p. 127-128), e McKirahan (1992, p. 35).

Manuscrito - Rev. Int. Fil., Campinas, v. 35, n. 1, p. 7-60, jan.-jun. 2012. 
se pode engendrar um silogismo correto que atenda apenas ao primeiro requisito - mas são estritamente necessários (sine quibus non) para a demonstração.

Mesmo sem compreender o que Aristóteles quer dizer com “princípios adequados", podemos dizer, então, que "adequados" são os princípios que fazem a demonstração ser o que ela é, e que não podem ser reduzidos aos princípios que decidem a validade formal de um silogismo. Nosso passo seguinte consiste em compreender o que Aristóteles entende por "princípios adequados". ${ }^{69}$

Embora seu pronunciamento em $71 \mathrm{~b} 22-23$ sugira que todos os seis requisitos fazem parte da noção de "adequação dos princípios", outros trechos mostram claramente que o primeiro requisito, o da verdade das premissas, não tem papel determinante para a adequação. É claro que todo princípio adequado deve ser também verdadeiro, mas, em 74b25-26, Aristóteles diz que "não é tudo que é verdadeiro que é adequado" . Com efeito, como já sugerimos, é possível obter, sobre um dado assunto que se quer conhecer cientificamente, um silogismo correto, com premissas verdadeiras, mas isso ainda é insuficiente para engendrar conhecimento científico, pois, como Aristóteles insiste em Segundos Analíticos I-9, o conhecimento científico aflora quando o objeto em pauta (o explanandum) é explicado pelos princípios que lhe cabem enquanto ele é ele mesmo, ou seja, pelos princípios que descrevem o que ele é essencialmente (76a5-6). No início de Segundos Analíticos I-9, Aristóteles é ainda mais claro: para se obter conhecimento científico, não basta nem mesmo proceder de princípios verdadeiros, imediatos e indemonstráveis (75b37-40), tampouco basta proceder de princípios verdadeiros e primeiros (76a28-30). Antes de

69 Discordo de McKirahan (1992), quando este diz: "since a principle is defined as a thing that is primary, it is redundant to call it appropriate" (p. 26); "“appropriate principle' is equivalent to 'principle of $x$ "' (p. 27) - afirmações que ignoram completamente a insistência de Aristóteles, em APo I-9, na insuficiência da "primariedade" das premissas.

Manuscrito - Rev. Int. Fil., Campinas, v. 35, n. 1, p. 7-60, jan.-jun. 2012. 
buscar entender o sentido dessas teses, convém considerar a seguinte questão. Se o que é próprio da demonstração e faz dela o que ela é são os princípios adequados, para melhor compreender a noção de "adequação", convém considerar em que consiste, para Aristóteles, a característica essencial da demonstração.

\section{VII.a) Demonstração, adequação e necessidade: ${ }^{70}$}

Demonstração, para Aristóteles, consiste em um silogismo que produz conhecimento científico (71b17-19). Ser um silogismo consiste no traço genérico da demonstração. ${ }^{71}$ Se queremos captar sua diferença essencial, devemo-nos ater ao outro fator, que introduz sua especificidade: produzir conhecimento científico. Ora, o traço essencial do conhecimento científico, conforme a definição proposta em 71b912 , consiste em conhecer algo pela sua causa, e por uma relação causal que não pode ser de outro modo. ${ }^{72}$ A causa em questão é uma causa necessária neste sentido: nenhuma outra causa pode dar, para o

70 Nesta sub-seção do artigo, retomo alguns pontos que desenvolvi em Angioni (2007). Os argumentos da sub-seção seguinte são independentes dos argumentos desta sub-seção (VII.a). Ainda que alguém não se dê por convencido a respeito do sentido que proponho para "necessário" na expressão "princípios necessários da demonstração cietífica", isso não afetará meu argumento na sub-seção seguinte (VII.b), a respeito da relação entre princípio adequado e essência.

71 Barnes (1981, p. 29), afirma: "in the Posterior Analytics, to be sure, Aristotle does not explicitly state that apodeixeis are syllogisms". Barnes não ignora 71b17-19, é claro, mas julga que "syllogismos" não designa a noção de silogismo. No entanto, é óbvio que a noção de silogismo interessa a Aristóteles por ser apta a expressar a estrutura triádica da causalidade, como fica claro pelo livro II dos Segundos Analíticos.

72 O antecedente retomado pelo pronome "touto", em 71b12, não é nem "aitia" nem "pragma", mas a sentença "hoti ekeinou aitia esti", ou seja: a relação causal. Que tal e tal causa seja a causa do fato em questão - eis o que não pode ser de outro modo.

Manuscrito - Rev. Int. Fil., Campinas, v. 35, n. 1, p. 7-60, jan.-jun. 2012. 
explanandum em pauta, a explicação adequada (embora outras causas possam dar explicações verdadeiras, mas não primeiras), de modo que, para obter conhecimento científico do explanandum em pauta, devemos encontrar essa causa, não outra. Isso faz dessa causa um "princípio necessário" (74b5-6).

Em 74b15-18, Aristóteles escreve: "a partir de itens verdadeiros, é possível ter um silogismo mesmo sem demonstrar, mas, a partir de itens necessários, não é possível ter silogismo a não ser demonstrando, pois é isso que é próprio da demonstração". A interpretação mais usual desse trecho julga que o termo "necessário", neste contexto, se aplica às proposições em si mesmas e introduz a propriedade de ser "necessariamente verdadeira", que consiste no objeto da silogística modal de Aristóteles. ${ }^{73}$ No entanto, diante da insistência de Aristóteles nos seis requisitos em 71b20-33 (bem como diante de sua insistência em critérios mais específicos, em 73a24-25ss.), seria obtuso julgar que Aristóteles agora estivesse a dizer que uma demonstração científica seria tão apenas um silogismo correto modalizado, isto é, um silogismo cujas três proposições fossem necessariamente verdadeiras. ${ }^{74}$ Se a necessidade assim concebida deve ser considerada ou não como uma característica das proposições científicas, é algo que não discutirei neste artigo, pois basta um ponto anterior, que não depende dessa discussão, a saber: ainda que esse tipo de necessidade seja uma das características

${ }^{73}$ Cf. Ross (1949, p. 528); Barnes (1993, p. 126); McKirahan (1992, p. 125-6); Mignucci (2007, p. 171); Lloyd (1981, p. 158), e mesmo Burnyeat (1981, p. 110).

74 Cf. Porchat (2000, p. 97): “[...] não acentuam algo que se nos afigura extremamente importante para a correta compreensão da teoria aristotélica da ciência: é a preocupação do filósofo em mostrar-nos [...] a possibilidade de abordarem-se as questões pertinentes ao domínio científico por raciocínios que, embora corretos e construídos sobre premissas verdadeiras e, mesmo necessárias, não constituem raciocínios verdadeiramente científicos, isto é, não nos proporcionam efetiva ciência daquilo que, por eles, se está conhecendo" (grifos meus).

Manuscrito - Rev. Int. Fil., Campinas, v. 35, n. 1, p. 7-60, jan.-jun. 2012. 
formais das proposições científicas, ela não é o foco de Aristóteles, quando ele emprega o vocábulo "necessário" para o caracterizar o traço mais essencial da demonstração científica.

Meu ponto é o seguinte: quando Aristóteles diz, em 71b12, que "isso não pode ser de outro modo", ele quer dizer que a relação causal adequada, capaz de engendrar conhecimento científico, não pode ser outra. ${ }^{75}$ Há apenas uma causa adequada (embora existam outras causas, capazes de fornecer explicações verdadeiras, mas não completas, nem últimas), e isso faz dessa causa a causa "necessária" para o conhecimento científico. Um mesmo explanandum pode ser explicado por mais de um princípio explanans, e esses múltiplos princípios, ainda que possam ser tomados como explicações "paralelas", que atentam a interesses distintos, podem ser organizados em uma série tal em que um explica o outro, sucessivamente. ${ }^{76}$ Essa sucessão, no entanto, não procede ad infinitum: há uma causa que fornece a explicação última, ou

${ }^{75}$ Filopono, 22.15-17, parece ter tido alguma percepção nesse sentido: "os que julgam que a Terra fica imóvel devido à vórtice agudo do céu julgam ter conhecimento científico (epistasthai), porque julgam que esta é a causa e julgam que a Terra não ficaria imóvel de outro modo". Também Burnyeat (1981, p. 109-110), sugere que o "necessário" de que Aristóteles fala em $71 \mathrm{~b} 12$ se refere a "lawlike connections" ou "necessary connections in nature".

76 Desenvolvi esse ponto com algum detalhe em Angioni (2009, p. 262-264). Podemos explicar por que serrotes são pesados recorrendo à causa material: são pesados porque são constituídos de material metálico (ferro ou bronze). No entanto, podemos explicar por que serrotes devem ser constituídos de material metálico recorrendo à causa final-formal: eles devem ser assim constituídos porque se definem essencialmente pela função de serrar madeira, que exige um material desse tipo. Para explicar, portanto, por que serrotes são pesados, podemos recorrer tanto à causa material como à causa final. A primeira explicação, no entanto, é subordinada à segunda, e é a segunda que nos fornece o fundamento último e primeiro que não mais exige nova pergunta.

Manuscrito - Rev. Int. Fil., Campinas, v. 35, n. 1, p. 7-60, jan.-jun. 2012. 
a explicação primeira, ${ }^{77}$ aquela que nos deixa inteiramente satisfeitos e não mais admite nem requer um fundamento anterior, bem como é capaz de explicar, em última instância, todas as explicações precedentes.

De modo similar, em 74b5-6, ao dizer que o conhecimento demonstrativo provém de princípios necessários, Aristóteles tem em vista o mesmo ponto. O que faz de uma proposição um princípio necessário - no uso específico do termo "necessário" pertinente neste contexto - não é sua característica modal, enquanto proposição isolada, mas o fato de, em dado contexto explanatório, tal proposição ser a única capaz de fornecer a explicação última e adequada do explanandum, de tal modo que tal proposição se torna, para aquele explanandum, um princípio necessário, sem o qual não se pode conhecê-lo cientificamente. Por isso, em 74b15-18, ao dizer que, se os princípios de um silogismo correto forem os necessários, haverá demonstração, Aristóteles quer dizer que a demonstração se perfaz quando o mediador, além de engendrar premissas verdadeiras, capta a causa adequada para explicar o fato relatado na conclusão - a causa que, não podendo ser outra, é o princípio necessário para a explicação que se pretende científica.

Podemos dizer, então, que princípio adequado e princípio necessário são, no contexto da teoria da demonstração científica, noções equivalentes. Devemos, porém, prosseguir na tarefa de elucidar em que consiste um princípio adequado. Ainda que o leitor não se dê por convencido a respeito da equivalência entre princípio adequado e princípio necessário, devemos tentar convencê-lo de que a adequação está diretamente ligada à essência do objeto a ser explicado, pois é a essência que é a causa capaz de fornecer a explicação última das propriedades relevantes do objeto.

${ }_{77}$ Cf. Física 195b21-25 ("causa mais alta”), 194b18-20 ("causa primeira") e Segundos Analíticos 85b27-30ss.

Manuscrito - Rev. Int. Fil., Campinas, v. 35, n. 1, p. 7-60, jan.-jun. 2012. 


\section{VII.b) Adequação e essência:}

Em 75b37-40, texto já citado, Aristóteles afirma que, para ter demonstração científica de uma dada coisa, não basta prová-la por princípios verdadeiros, imediatos e indemonstráveis. Essa passagem poderia dar razão aos que rejeitam a intepretação que antes sugeri para o requisito da "imediatez" das premissas. Havia sugerido que a "imediatez" de uma premissa não seria a característica meramente formal de não admitir mediador algum que permitisse sua dedução silogística. Ao insistir no laço intrínseco entre imediatez e causalidade, havia sugerido que a imediatez seria a característica de não haver mediador que permitisse explicar, por causas mais básicas, a relação entre sujeito e predicado na premissa em questão. No entanto, se a imediatez já fosse tão intrinsecamente conectada com a noção de causa primeira, se poderia dizer que não haveria como compreender o trecho 75b37-40.

Minha resposta a essa objeção é simples. Há pleno acordo entre 75b37-40 e 71b20-22: proposições são imediatas no sentido de que a relação entre sujeito e predicado nelas afirmada não pode ser explicada por nenhuma causa mais básica. ${ }^{78}$ Mas, em 75b37-40, torna-se claro que a imediaticidade, somada à verdade, pode não ser capaz, por si mesma, de explicar um dado explanandum. A imediaticidade é uma característica que considera uma premissa em sua relação com outras proposições que lhe fossem anteriores - relação, de fato, inexistente - , sem considerar a relação entre tal premissa e outras proposições que pudessem ser deduzidas e/ou explicadas por meio dela. É claro, porém, que a demonstração diz respeito à relação das premissas com outras proposições que possam ser explicadas por meio delas. A noção de princípio adequado, portanto, não pode esgotar-se na relação “para

\footnotetext{
${ }^{78}$ Esse requisito não é satisfeito, por exemplo, pela proposição "a função de serrar exige materiais que são pesados", nem pela proposição "todo triângulo tem $2 \mathrm{R}$ ".
}

Manuscrito - Rev. Int. Fil., Campinas, v. 35, n. 1, p. 7-60, jan.-jun. 2012. 
trás" entre premissas e outras premissas que lhes fossem ainda anteriores. A noção de princípio adequado envolve a relação "para frente" entre premissas e outras proposições que possam ser explicadas pelas premissas. Por isso, é bem evidente que a imediaticidade das premissas, somada à verdade, ainda é insuficiente para a demonstração científica. É também preciso que a premissa imediata seja adequada ao explanandum, no sentido de ser comensurada ao atributo a ser explicado e tomar o sujeito do explanandum de acordo com a descrição relevante da qual depende, em última instância, a atribuição do predicado que se quer explicar. É claro, portanto que a "imediatez" de uma premissa pode não ser suficiente para explicar adequadamente a conclusão, quando a premissa não toma o sujeito da conclusão de acordo com a descrição essencial relevante apta a explicar, de modo comensurado e completo, porque o sujeito tem o atributo relatado na conclusão. O fato de algo ser "imediato" no sentido de não depender de nenhuma causa anterior não faz dele algo "adequado" para explicar um dado explanandum.

Algo similar vale para o adjetivo "primeiro" em 76a28-30, embora se deva notar que, nessa passagem, o termo não é usado exatamente do mesmo modo como foi proposto em 72a5-6. Se não evocamos a noção de adequação (que de fato está ausente em 76a2830), podemos dizer que "primeira" seria a premissa que não pudesse ser explicada por nenhuma outra mais básica. Essa exigência consiste apenas em dizer que a premissa deve ser inaugural em uma cadeia de relações causais, mas por si só não envolve a exigência suplementar de que a premissa deve ser comensurada e apropriada ao que se propõe a explicar. Essa exigência suplementar se encontra claramente em 72a5-6, quando a noção de "primeiro" é associada à noção de "adequado". Em Segundos Analíticos I-9, Aristóteles mostra o risco de confusão em que incorremos se não compreendemos a noção de "primeiro" em conjunto com a noção de adequação (a qual é então resgatada pela exigência de homogeneidade entre os termos da demonstração, em 76a8-9, 29-30). Na quadratura do círculo proposta por Brisão, uma 
premissa maior "imediata" e supostamente "primeira" é aplicada para estabelecer que pode haver um círculo cuja área seja igual à de um quadrado. ${ }^{79}$ Talvez a prova de Brisão seja incapaz até mesmo de estabelecer que existe um círculo com área igual a de um quadrado, ${ }^{80}$ mas o ponto fulcral de Aristóteles é que, como tentativa de explicar por que um círculo teria sua área igual a de um quadrado, a proposta de Brisão é fatalmente inadequada, por assumir princípios que não são relevantes para explicar o que pretendia explicar.

No entanto, o exemplo mais elucidativo sobre a noção de adequação explanatória se encontra em Segundos Analíticos I 5, pelo qual se podem elucidar não apenas as características extensionais da noção de "princípio adequado" ou "causa primeira", mas também as características intensionais que ligam a noção de adequação à noção de essência. Trata-se de uma suposta demonstração na qual, pretendendo explicar porque o triângulo tem a soma de seus ângulos internos igual a dois ângulos retos (doravante, 2R), se tomasse como mediador a

79 O exemplo da quadratura de Brisão é bem controverso, porque a informação sobre o mesmo é escassa e de "segunda mão". Nossa fonte é Filopono 111.20-30 ss., mas o próprio Filopono já deixa claro que o exemplo era controverso na antigüidade. Uma reconstituição minimamente razoável do argumento (com omissão de vários passos dedutivos) poderia ser a seguinte: (i) Existe um dado quadrado Q1, que circunscreve o círculo C, e, portanto, é maior que o círculo C. (ii) Existe um dado quadrado Q2, inscrito no círculo C, e, portanto, menor que o círculo C. (iii) Há um quadrado Q3 que é maior que Q2, mas menor que Q1. (iv) Ora, também o círculo C é maior que Q2, mas menor que Q1. (v) "são iguais entre si as coisas que são maiores e menores que uma mesma terceira coisa" (111.27-28); logo, (vi) o círculo C é igual ao quadrado Q3. O argumento parece ser válido, mas a premissa (v) é um caso de "assunção não-verdadeira no domínio de uma ciência" (Tópicos 101a13-15), ou um caso de premissa inapropriada ao assunto (Refutações Sofísticas 171b17-18, 20-22).

${ }^{80}$ Cf. "se é que de fato se fez a quadratura do círculo" (Ref. Sof. 171b16-17).

Manuscrito - Rev. Int. Fil., Campinas, v. 35, n. 1, p. 7-60, jan.-jun. 2012. 
descrição "ou isósceles, ou escaleno, ou equilátero". ${ }^{81} \mathrm{O}$ resultado seria o seguinte silogismo: "Tudo que é ou isósceles, ou escaleno, ou equilátero tem 2R; todo triângulo é ou isósceles, ou escaleno, ou equilátero; logo, todo triângulo tem 2R". Todas as proposições desse silogismo são não apenas verdadeiras, mas também necessariamente verdadeiras. Além do mais, o mediador assumido é coextensivo aos dois termos que constituem a proposição a ser explicada: de fato, o predicado "ou isósceles, ou escaleno, ou equilátero" se aplica a todo triângulo e apenas a triângulos. Não obstante, esse mediador não capta a propriedade relevante que faz o triângulo ter $2 \mathrm{R}$. A propriedade relevante que faz o triângulo ter $2 \mathrm{R}$ é ser uma figura plana retilínea de três lados, que se atribui coextesivamente ao triângulo e capta aquilo que o faz ser triângulo e não outra coisa: trata-se da essência do triângulo. É essa propriedade que explica adequadamente por que o triângulo tem 2R e, nesse caso, o termo mediador, que pretende introduzir a explicação, é "congênere" (76a30) ao "primeiro do gênero" (74b25), o triângulo, sobre o qual se conduz a demonstração. Essa propriedade é um princípio do triângulo "enquanto ele é ele mesmo e não outra coisa" 82 - trata-se, enfim, da definição do triângulo, ou de

81 Cf. Ross (1949, p. 526). Poder-se-ia argumentar que o predicado "ou isósceles, ou escaleno, ou equilátero" se aplicaria verdadeiramente a qualquer item que satisfizesse um dos disjuntos, por exemplo: quadrados, que são equiláteros. A forma do predicado não é, porém, esse tipo de disjunção. A forma do predicado é uma disjunção exaustiva: o predicado só pode ser aplicado verdadeiramente ao item cuja extensão é exaurida por subconjuntos não-vazios que atendem a cada um dos disjuntos.

${ }^{82}$ Cf. 74a12 ss.; 76a5-6; 85b5-6 ss. Barnes (1993, p. 118-9), toma a expressão "as such" (hei auto, enquanto X é X) como uma marca de que a proposição à qual a expressão se aplica é imediata: se A se atribui a C “as such", então A não se atribui a nenhum termo anterior que pudesse ser usado como mediador para provar AaC. Não surpreende que, uma vez acolhida essa tese absurda, Barnes (ib., p. 135) afirme, a respeito de 75b37ss.: "if Aristotle's words are to be pressed here, he will have to abandon the possibility of demonstrative knowledge". A expressão "hei auto", no entanto, é usada para demarcar o Manuscrito - Rev. Int. Fil., Campinas, v. 35, n. 1, p. 7-60, jan.-jun. 2012. 
atributos incluídos na definição do triângulo. ${ }^{83}$ Assim, quando uma demonstração se constrói de acordo com essas condições, temos conhecimento científico de que "todo triângulo tem 2R" pelos "princípios de cada coisa enquanto cada coisa é precisamente o que é" (76a4-7), ou seja, pelos princípios do triângulo enquanto triângulo. ${ }^{84}$ É nesse caso que se satisfaz plenamente o requisito de que a demonstração deve exibir o princípio adequado, ou o princípio necessário - que não é senão a causa primeira que não pode ser de outro modo.

\section{Conclusão}

Os seis requisitos para as premissas da demonstração científica propostos em 71b20-33 têm sido interpretados como (i) algo independente da armadura silogística que Aristóteles impõe à demonstração em 71b17-19,85 (ii) algo mal conectado com a definição

aspecto de $\mathrm{C}$ segundo o qual podemos explicar apropriadamente por que $\mathrm{C}$ é A (cf. Kosman (1973)): "enquanto C é o que C é" quer dizer enquanto C tem as propriedades essenciais que o fazem ser o que ele é.

${ }^{83}$ Cf. Mignucci (2007, p. 179). Para interpretação dos silogismos sugerido em APo 74a25-32, ver Hasper (2006, p. 269-278), e Harari (2010, p. 60).

${ }_{84}$ Neste parágrafo, estou a pressupor vários pontos em favor dos quais argumentei em Angioni (2007). Sobre a sintaxe tortuosa de 76a4-7, alguns (Ross (1949, p. 537); Barnes (1993, p. 135)) julgam que Aristóteles remete aos princípios do termo médio usado na prova de que todo triângulo tem $2 \mathrm{R}$. No entanto, já em minha tradução em Angioni (2004), defendi que Aristóteles fala dos princípios do triângulo. Cf. Mignucci (2007, p. 179); Pellegrin (2005, p. 359).

${ }^{85}$ Cf. Barnes (1981, p. 33): “Apodeictic does not depend essentially on the theory of the Syllogism: none of the central conditions of principlehood is Syllogistic". Em direção oposta, ver Burnyeat (1981, p. 121), McKirahan (1992, p. 25), e Hintikka (1972, p. 55): "One is almost tempted to say that Aristotle's views on the first principles of a science are predictable on the basis of his syllogitic theory".

Manuscrito - Rev. Int. Fil., Campinas, v. 35, n. 1, p. 7-60, jan.-jun. 2012. 
de conhecimento científico dada em 71b9-12 e (iii) algo cuja relação com os demais requisitos da demonstração científica, propostos em Segundos Analíticos I 4-5, I-6 e I-9, é no mínimo obscura. Poder-se-ia acrescentar, ainda, que (iv) a relação entre os seis requisitos em si mesmos, com poucas exceções, estaria longe de ser coerente e orgânica. ${ }^{86}$ Julgamos ter mostrado que esses quatro pontos são falsos.

$\mathrm{O}$ primeiro requisito pode, de fato, ser entendido independentemente da referência à silogística, mas o mesmo não pode ser dito dos demais requisitos. É claro que, em certo sentido, os termos "primeiro", "anterior" e "mais conhecido" podem ser entendidos independentemente de qualquer estrutura silogística. No entanto, o modo pelo qual Aristóteles os usa no contexto em pauta depende intrinsecamente da estrutura silogística da demonstração. Aos que ignoram a real motivação de Aristóteles ao impor a estrutura silogística à demonstração científica, bem como ignoram o propósito essencial que anima e define a concepção aristotélica de demonstração científica,

86 Barnes (1993, p. 93), afirma que, a respeito dos seis requisitos, “Aristotle's thoughts have two irritating imprecisions": a de não ter distinguido entre relações de dependência epistemológica e relações de dependência lógica, e a de não ter traçado nenhuma distinção "between the principles on which a demonstrated conclusion ultimately depends and the premises from which it immediately derives" (cf. McKirahan (1992, p. 29), sobre a diferença entre "grounds" e "principles"). Não discuti o primeiro ponto neste artigo, mas, quanto à segunda acusação de Barnes, julgo que ela deriva unicamente do fato de Barnes não ter entendido que o propósito básico da demonstração consiste em explicar uma conclusão pela causa apropriada. Além do mais, Barnes (ib., p. 96), após afirmar que "Aristotle plainly treats priority (in the relevant sense) and greater familiarity as one and the same thing", conclui que "we should properly speak of five, rather than six, conditions on the premisses or principles of demonstration". Pior ainda é a posição de Kiefer (2007, p. 79), que reduz os três últimos requisitos aos três primeiros: "they are not further, additional items. [...] if a statement is true, primary and immediate, and is recognized as such, it will be more recognized than, prior to, and the cause of the conclusion derived from that statement".

Manuscrito - Rev. Int. Fil., Campinas, v. 35, n. 1, p. 7-60, jan.-jun. 2012. 
é fácil acolher as acusações contidas nos pontos (ii) a (iv) há pouco mencionados.

Primeiramente, é preciso insistir que o propósito essencial que anima e define a concepção aristotélica de demonstração científica é o da explicação adequada, e não o da prova - se por "prova" se entende um argumento correto que estabelece ou certifica a verdade de uma proposição. Muitos intérpretes julgam que a motivação básica da teoria da demonstração em Aristóteles seria encontrar um método de prova pelo qual (a) se poderia decidir o valor de verdade de proposições problemáticas (e, portanto, provar que elas são verdadeiras, como se isso estivesse sob questão) ${ }^{87}$, bem como avançar o conhecimento no sentido de encontrar novas proposições verdadeiras, cuja verdade antes se ignorava. ${ }^{88}$ Além do mais, esse método de prova (b) dependeria, em última instância, de verdades primeiras, auto-evidentes e, portanto, axiomáticas - proposições não apenas aptas a transmitir o valor de verdade às conclusões por força da validade formal das provas, mas também aptas a dar à verdade das conclusões uma garantia última. Essa interpretação, no entanto, não se sustenta. É claro que seus adeptos têm toda a razão em lamentar que Aristóteles tenha imposto à demonstração a forma do silogismo, bem estéril no que concerne ao “avanço do conhecimento". No entanto, afirmo que a motivação básica da teoria aristotélica da demonstração científica não consiste nem em decidir o valor de verdade de proposições problemáticas nem em avançar o conhecimento no sentido de descobrir novas proposições verdadeiras antes ignoradas. Ainda que o cientista possa, em seu esforço de investigação, descobrir novas proposições verdadeiras e decidir o valor de verdade de proposições problemáticas, sua motivação

${ }^{87}$ Cf. Corcoran (2009, p. 1): "For Aristotle, starting with premises known to be true and a conclusion not known to be true, the knower demonstrates the conclusion by deducing it from the premises-thereby acquiring knowledge of the conclusion" (grifos meus).

${ }^{88}$ Contra esse painel, ver Burnyeat (1981, p. 136-137).

Manuscrito - Rev. Int. Fil., Campinas, v. 35, n. 1, p. 7-60, jan.-jun. 2012. 
básica consiste em explicar - e explicar adequadamente, pela causa primeira - por que são verdadeiras certas proposições cuja verdade já se conhecia de antemão. Ainda que o ponto de partida na investigação científica possa ser, eventualmente, uma proposição problemática cujo valor de verdade não está ainda decidido ("será que S é P, ou não?"; “será que existe vazio, ou não?”), a tarefa mais básica da investigação científica, na qual ela unicamente se completa, consiste em encontrar uma explicação adequada para a verdade de certas proposições. Problemas científicos genuínos não têm por forma básica a estrutura “será que S é P, ou não?", mas antes a estrutura "por que S é P?", estando, no mais das vezes, já decidido que S é P. Um filósofo da ciência pode lamentar que Aristóteles tenha tido tal concepção, mas é essa concepção que o exegeta do texto aristotélico deve-lhe atribuir.

Por outro lado, contra o ponto (b), devemos dizer que a exigência de premissas axiomáticas, cuja verdade seja imediata e autoevidente, se esvai por completo, tão logo compreendemos que é a noção de explicação adequada que ocupa o centro das atenções de Aristóteles. É claro que as premissas da demonstração científica devem ser verdadeiras, bem como é claro que, em última instância, elas não podem ser explicadas por causas mais básicas. No entanto, como o ponto central não mais é a mera exigência de garantir o valor de verdade pela validade formal da prova, não mais se exigem, sob pena de regresso ao infinito, proposições cuja verdade fosse evidente por sua mera forma, e que não pudessem de modo algum ser estabelecidas por nenhuma prova correta. Para Aristóteles, as premissas primeiras são primeiras por terem papel explanatório fundamental. De fato, elas não podem ser explicadas por princípios mais básicos, mas isso nada tem a ver com a forma lógica das mesmas e deixa em aberto a possibilidade de se deduzi-las em silogismos corretos (como nos silogismos em que os três termos são coextensivos entre si).

Assim, a motivação básica de Aristóteles, ao impor à demonstração a estrutura silogística, está longe ser o "ideal da axiomatização". Embora Aristóteles reconheça e louve as propriedades 
estritamente formais do silogismo, sua escolha não parece fundada nesse ponto. Aristóteles elege o silogismo como ferramenta formal da demonstração pelo simples fato de que o silogismo, sobretudo na primeira figura, se presta a captar as relações de causalidade. ${ }^{89}$ Como já disse, a relação causal, para Aristóteles, se dá em uma estrutura triádica: o explanandum consiste em uma relação predicativa entre um sujeito $C$ e uma dada propriedade $A$, e a causa consiste em outra propriedade mais básica, B, a qual, presente no sujeito C, faz esse sujeito ter a propriedade A. A causa se expressa como "mediador" na estrutura do silogismo (90a6-11). E a relação intrínseca entre a preocupação central com a causalidade e a forma do silogismo se faz sentir já na exposição das seis exigências das premissas, em 71b20-33. Como já disse, no contexto de 71b20-33 (cf. 72a7-8), "imediata" é a premissa para a qual não se pode encontrar um mediador explanatoriamente mais básico pelo qual se explicasse por que o predicado de tal premissa se atribui a seu sujeito. Essa exigência, no entanto, não requer que a premissa seja imediata também no sentido de que não se possa encontrar nenhum mediador pela qual sua verdade pudesse ser provada em um silogismo correto.

Assim, a preocupação central com a causalidade, expressa no requisito de ser causa, também determina o requisito da imediaticidade.

${ }^{89}$ Por isso discordamos de Smith (2009, p. 53): "Since he [i.e. Aristóteles] believes that the syllogistic is the only correct theory of inference, he also believes that the premises of a demonstration must have the forms recognised by that theory". Como procurei mostrar, a motivação de Aristóteles para a escolha do silogismo como instrumento de demonstração não é "lógicoformal", por mais que Aristóteles também tenha se entusiasmado com as propriedades estritamente lógicas da silogística. Também não julgamos correto afirmar, como faz Lear (1980, p. 13), que o motivo que levou Aristóteles a estudar um sistema formal particular (a silogística) tenha sido esclarecer a natureza da prova (isto é, da apodeixis científica). Ainda mais discordamos de Hintikka (1972, p. 57), que sugere que "the transitivity of class-inclusion" seria a característica principal da noção aristotélica de explicação científica.

Manuscrito - Rev. Int. Fil., Campinas, v. 35, n. 1, p. 7-60, jan.-jun. 2012. 
A rigor, a preocupação central com a causalidade, já expressa na definição de conhecimento científico em 71b9-12, determina também os sentido mais preciso dos demais requisitos, como já vimos. As premissas devem ser anteriores não no sentido meramente formal segundo o qual premissas de qualquer argumento correto são suficientes para acarretar a verdade da conclusão, mas do modo pelo qual se diz que a causa é anterior àquilo de que é causa. De modo similar, as premissas devem ser mais conhecidas não porque "a verdade delas se depreende de seu próprio sentido" ou porque, se assim não fosse, não se garantiria a transmissão do valor de verdade no argumento sem evitar o regresso ao infinito, mas porque elas expressam a causa que faz a conclusão ser cientificamente conhecida. Além do mais, as premissas devem ser primeiras no sentido de "adequadas" ao explanandum em pauta, e isso novamente traz ao centro das atenções a noção de causa. Pode-se acrescentar que também o requisito da verdade está envolvido com a preocupação central com a causalidade, visto que é impossível explicar pela causa algo que não é o caso, bem como é impossível explicar algo por premissas falsas (ver Primeiros Analíticos 53b8-10).

Assim, nota-se que há, contrariamente ao ponto (iv), estrita organicidade entre os seis requisitos das premissas. De modo similar, dado que a estrutura silogística é eleita por Aristóteles como instrumento de demonstração por ser apta a exprimir relações causais, é falso dizer - como diz o ponto (i) - que as seis características das premissas não têm nenhuma relação com a forma silogística e poderiam até mesmo ser compreendidas independentemente da forma silogística. Além do mais, os seis requisitos das premissas estão intrinsecamente conectados com a definição de conhecimento científico dada em 71b912 , em termos de causa e necessidade - pois a necessidade em questão não é outra senão a necessidade da causa primeira, que é a única causa apta a explicar de modo pleno e adequado o explanandum em pauta. Finalmente, dado que a noção de explicação adequada é mais bem explorada por Aristóteles no capítulo 9, no qual ele alerta contra 
interpretações indevidas dos requisitos $\mathrm{da}$ imediaticidade $\mathrm{e}$ da primariedade, bem como no capítulo 6 , no qual a adequação é relacionada à noção de "princípio necessário"; e como a noção de princípio necessário pressupõe as relações predicativas que Aristóteles procurou descrever nos capítulos 4 e 5 , tanto em suas propriedades extensionais como em suas propriedades intensionais, pode-se concluir que os seis requisitos das premissas têm uma relação bem orgânica com ulteriores desenvolvimentos da noção de demonstração científica no livro I dos Segundos Analíticos.

\section{Referências Bibliográficas}

ANAgnOSTOPOUlOS, G. A Companion to Aristotle. Oxford: WileyBlackwell, 2009.

ANGIONI, L. "Explanation and Definition in Physics I-1". Apeiron 34:4, pp. 307-319, 2001.

" "O conhecimento Científico no Livro I dos Segundos Analíticos de Aristóteles". Revista de Filosofia Antiga, vol. I, no 2, 2007. Disponível em http://www.filosofiaantiga.com/ documents/Lucas-2007-2.pdf.

ANGIONI, L. As Noções Aristotélicas de Substância e Essências. Campinas: Editora da Unicamp, 2008.

—. Aristóteles, Física I-II, Campinas: Editora da Unicamp, 2009. " "Prioridade e Substância na Metafísica de Aristóteles", Dois Pontos 7: 3, pp. 75-106, 2012.

BARNES, J. “The Aristotle's Theory of demonstration". In Barnes, J., Schofield, M. \& Sorabji, R. (eds.) (1975), pp. 65-87. 59. 
BARNES, J. Posterior Analytics. Second edition. Oxford: Oxford University Press, 1993. ., SCHOFIELD, M. \& SORABJI, R. Articles on Aristotle. London: Duckworth, 1975.

BERTI, E. Aristotle on Science. Padova: Antenore, 1981.

BURNYEAT, M.F. “Aristotle on Understanding Knowledge”. In Berti, E.(ed.) (1981), pp.97-140.

CHARLES, D. Aristotle on Meaning and Essence. Oxford: Oxford University Press, 2000.

CORCORAN, J. "Aristotle's Demonstrative Logic". History and Philosophy of Logic, 30:1, pp. 1-20, 2009.

LEE, E., MOURELATOS, N, and RORTY, R. Exegesis and Argument. Assen: Van Gorcum, 1973.

EVERSON, S. Epistemology. Cambridge: Cambridge University Press, 1990.

KIEFER, T. Aristotle's Theory of Knowledge. London/NY: Continuum, 2007.

KOSMAN, L. A. "Explanation, Understanding and Insight in Aristotle's Posterior Analytics". In Lee, E. Mourelatos, N. and Rorty, R (eds.) (1973), pp. 374-392.

HASPER, P. "Sources of Delusion in Analytica Posteriora I.5". Phronesis, 51, pp. 252-284, 2006.

HARARI, O. Knowledge and Demonstration: Aristotle's Posterior Analytics. Dordrecht: Kluwer, 2010.

HINTIKKA, J. "On the ingredients of an Aristotelian science". Nous, 6, pp. 55-69, 1972. 
LEAR, J. Aristotle and Logical Theory. Cambridge: Cambridge University Press, 1980.

LLOYD, A. C. "Necessity and Essence in the Posterior Analytics". In Berti, E. (ed.) (1981), pp. 157-171.

McKIRAHAN, R. Principles and Proofs. Aristotle's Theory of Demonstrative Science. Princeton: Princeton University Press, 1992.

MIGNUCCI, M. Aristotele - Analitici Secondi. Roma-Bari: Ed. Laterza, 2007.

PELlEGRIN, P. Aristote - Seconds Analytiques. Paris: GF Flammarion, 2005.

PERAMATZIS, M. Priority in Aristotle's Metaphysics. Oxford: Oxford University Press, 2011.

PORCHAT, O. Ciência e Dialética em Aristóteles. São Paulo: Ed. UNESP, 2000.

ROSS, W. D. Aristotle's Prior and Posterior Analytics. Oxford: Oxford University Press, 1949.

SCHOLZ. H. "The Ancient Axiomatic Theory". In Barnes, J., Schofield, M. \& Sorabji, R. (eds.) (1975) vol. 1, pp. 50-64.

SMITH, R. “Aristotle's theory of demonstration”. In Anagnostopoulos, G. (ed.) (2009), pp. 51-65.

STRIKER, G. Aristotle's Prior Analytics - Book I. Oxford: Oxford University Press, 2009.

TAYLOR. C. C. W. “Aristotle's epistemology”. In Everson, S. (ed) (1990), pp.116-142.

TIERNEY, R “Aristotle's Scientific Demonstrations as Expositions of Essence". Oxford Studies in Ancient Philosophy, 20, pp. 149-170, 2001. 